Brit. J. industr. Med., 1949, 1, 1.

\title{
CHEMICAL CARCINOGENESIS: A REVIEW
}

\section{HIEGER}

The Chester Beatty Research Institute, Royal Cancer Hospital, London (RECEIVED FOR PUBLICATION, JUNE 9, 1948)

Twenty authors who are themselves engaged in some branch of the chemical aspect of cancer research have contributed eighteen well documented specialist articles to a double number of the British Medical Bulletin.*

\section{Chemistry of Carcinogenic Compounds}

The first of the eighteen articles, which is by Haddow and Kon, on the chemistry of carcinogenic compounds, begins with Percival Pott (1775) and leads the history of the subject via Yamagiwa to Kennaway's work on synthetic tars (Kennaway, 1924, 1925 ; Kennaway and Hieger, 1930) and his discovery $\dagger$ of the first cancer producing hydrocarbon, $1: 2: 5: 6$-dibenzanthracene (Fig. 1).

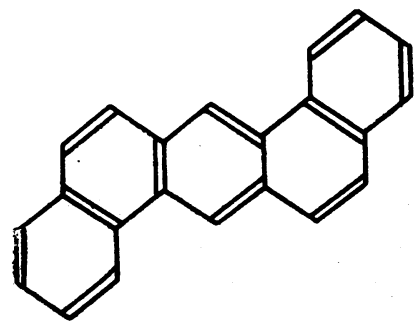

Fig. 1.-1 $1: 2: 5:$ 6-dibenzanthracene.

The Benzanthracene Story.-The application of fluorescence spectroscopy to the study of carcino-

- British Medical Bulletin, Vol. 4, nos. 5 and 6, 1947, price 10s. The writers are :

Haddow, A., and Kon, G. A. R. : "The Chemistry of Carcinogenic Compounds."

Berenblum, I.. Holiday, E. R., and Jope, E. M. : "Some Physical

Methods of Investigating Carcinogenic Hydrocarbons."

Methods of Investigating Carcinogenic Hydroca

Haddow, A.: " Mode of Action of Carc

Berenblum, I. : " Co-Carcinogenesis."

Crabtree, H. G. : "Anti-Carcinogenesis."

Dickens, F.: "The Influence of the Solvent on the Carcinogenic Response."

Boyland, E., and Weigert, F. : “Metabolism of Carcinogenic Compounds."

Hieger, I. : "Carcinogenic Substances in Human Tissues."

Peacock, P. R.: "The Carcinogenic Action of Heated Fats and Lipoids."

Burrows, H., and Horning, E. S. : " Oestrogens and Neoplasia."

Dodds, E. C.: "A Note on the Carcinogenic Action of Stilbene

Derivatives"

Bonser, G. M. : " Experimental Cancer of the Bladder."

Bielschowsky, F. : "The Carcinogenic Action of 2-Acetylaminofluorene and Related Compounds."

Orr, J. W. : "The Production of Liver Tumours by Azo Compounds."

Henry, S. A. : "Occupational Cutaneous Cancer Attributable to Certain Chemicals in Industry,"

Certain Chemicals in Industry."

Currie, A. N. : "The Role of Arsenic in Carcinogenesis."

Goldblatt, M. W.: " Occupational Cancer of

+ For a slightly more detailed description see Hieger, Symposium on Tar and Pitch Cancer in the British Journal of Radiolog.v, vol. 20, 1947 , p. 145 . genic substances proved to be the indispensable technique, in Kennaway's words " the single thread that led all through this labyrinth," for the success of his work and, of course, for the tracking down and isolation of $3: 4$-benzpyrene (fig. 2) Irom pitch.

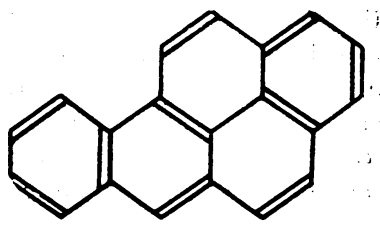

Fig. 2.-3 : 4-benzpyrene.

Fluorescence spectra had suggested that a derivative of $1: 2$-benzanthracene (fig. 3 ) was the<smiles>c1ccc2cc3c(ccc4ccccc43)cc2c1</smiles>

Fig. 3.-1:2-benzanthracene.

carcinogenic factor in tar, and in fact such proved to be the case, for whatever terminology is applied to benzpyrene, its structural relation to $1: 2$-benzanihracene is unmistakable and the similarity is supported by the extraordinarily close resemblance of the two fluorescence spectra, which are rather different from the spectrum of $1: 2: 5: 6$-dibenzanthracene.

As soon as one carcinogenic hydrocarbon became known, research was set going on the synthesis and testing of other hydrocarbons which were chemical variations on the structure of diberizanthracene. Benz-rings were added and substracted, alkyl groups were substituted in different positions in the nucleus, hexagon rings were replaced by pentagon rings, $C$ was substituted by $\mathrm{N}$ and by $\mathrm{S}$, and as a result of all this activity the number of compounds which have been tested for carcinogenic activity must now be counted in thousands. Hartwell's compilation (published in 1941 from the U.S. National Cancer Institute) catalogues along with authors'; references, mode of administration of the compounds, and 
carcinogenic potencies, nearly seven hundred compounds.

If all the publications on the different branches of cancer research were classified it would be found that, with the exception perhaps of the technique and theory of radiation therapy in cancer, the study of chemical carcinogens would head the list in respect of numerical precedence. The reasons for this flood of papers are obvious; the technique of organic synthesis is highly developed, and the tests can be carried out by the simplest means. Nevertheless, no really satisfactory generalization relating structure to carcinogenesis has yet been drawn from the study of these numerous compounds; and, indeed, as the number of carcinogens continues to increase, generalization will become more and more difficult, since it will be necessary to explain the activity of compounds of widely different structure.

On close examination any generalization that has been drawn can be shown to be merely a re-statement in more imposing language of the known facts.

At first it was thought that the mere addition of substitution groups in the benzanthracene molecule would suffice to confer carcinogenicity ; then it was found that the group (for example $\mathrm{CH}_{3}$ ) must be in certain positions on the molecule. Further, it became clear that the position of the additional benz-ring in $1: 2: 5: 6$-dibenzanthracene (fig. 1) was critical because the analogues $1: 2: 7: 8$ dibenzanthracene (fig. 4) and 1:2:3:4-dibenzanthracene (fig. 5) were almost inactive.<smiles>c1ccc2c(c1)ccc1cc3ccc4ccccc4c3cc12</smiles>

Fia. 4.-1 $1: 2: 7:$ 8-dibenzanthracene.<smiles>c1ccc2c3cc4ccccc4c4ccccc4c-3cc2c1</smiles>

Fic. 5.-1 $: 2: 3$ : 4-dibenzanthracene.

It was also telieved at first that a condensed five-ring system uas essential for carcinogenic potency ; then it was found that four rings would suffice ; in the last few years derivatives of three- ring systems have been shown to be carcinogenic ; and, finally, urethane (ethyl carbamate) must represent the simplest carcinogen to date.

It soon became obvious that simple variations in the chemical structure of a carcinogenic compound could profoundly influence the potency. For example, $1: 2$-benzanthracene is almost inactive carcinogenically, and the insertion of a methyl group in position $1^{\prime}$ or $2^{\prime}$ or $3^{\prime}$ or 3 is without effect, but when the group is in position 4, carcinogenic potency begins to appear, in position 5 the potency is quite high, and in 9 or 10 it is at its maximum ; and when both 9- and 10- are substituted the resulting compound, 9 : 10-dimethyl-1 : 2-benzanthracene (fig. 6), represents the most potent carcinogenic compound known.<smiles>Cc1c2ccccc2c(C)c2c1ccc1ccccc12</smiles>

FIG. 6. -9 : 10-dimethyl-1 : 2-dibenzanthracene.

Further work soon revealed unsuspected difficulties in the effort to correlate chemical structure and carcinogenic potency. For example, the introduction of a third and fourth methyl group decreased the activity of the compound ; and if the two methyl groups were disposed in certain positions, $1^{\prime}: 10$ or $3: 9-$, the resulting dimethyl-dibenzanthı acenes showed no activity when they were tested biologically.<smiles></smiles>

FIG. 7.-1' : 10-dimethyl-1 : 2-benzanthracene.<smiles>Cc1cccc2ccccc12</smiles>

Fig. 8.-3 : 9-dimethyl-1 : 2-benzanthracene. 


\section{Techinique of Testing Carcinogens}

Haddow and Kon assume that the reader is familiar with the technique of testing the carcinogens, but a brief description here may interest the reader. The two commonest methods of testing are either to paint a solution of the compound, in benzene or acetone or liquid paraffin, on the interscapular skin of the mouse twice a week until papillomas and then epitheliomas appear; or alternatively, to inject a solution of the compound, in lard or vegetable oil or tricaprylin or cholesterol, subcutaneously into the mouse : often one injection only is given.

The potency is measured by the proportion of tumours obtained, by the length of the latent period, or by some combination of both, but such estimations are rather approximate especially if the activity is not very pronounced. In Tables 1, 2, and 3, taken from the paper by Hieger (1947) referred to above, are reproduced results of experiments on quantitative tumour production.

TABLE 1

TUMOUR PRODUCTION IN MICE BY CARCINOGENIC HYDROCARBONS: TABLE SHOWING DIFFERENCES IN CARCINOGENIC POTENCIES MEASURED BY VARIATIONS OF (a) LATENT PERIOD, AND (b) YIELD OF TUMOURS

\begin{tabular}{|c|c|c|c|}
\hline \multirow[b]{3}{*}{$\begin{array}{l}\text { Methylcholanthrene } \\
1: 2: 5: 6 \text {-dibenzanthracene } \\
3: \text { 4-benzpyrene .. }\end{array}$} & \multicolumn{2}{|c|}{$\begin{array}{l}\text { Average latent } \\
\text { period (days) }\end{array}$} & \multirow[b]{2}{*}{ Tumours* } \\
\hline & $\begin{array}{c}\text { Subcu- } \\
\text { taneous } \\
\text { applica- } \\
\text { tion }\end{array}$ & $\begin{array}{l}\text { Skin } \\
\text { applica- } \\
\text { tion }\end{array}$ & \\
\hline & $\begin{array}{r}91 \\
165 \\
107\end{array}$ & $\begin{array}{l}126 \\
213 \\
144\end{array}$ & \\
\hline $\begin{array}{l}9: \text { 10-dimethyl-1 : 2-benzan- } \\
\text { thracene } . \\
\text { Methylcholanthrene }(a) \quad \ldots \\
\text { Methylcholanthrene }(b) \ldots \\
3 \text { 4-benzpyrene (from } \\
\text { pitch) } \ldots \\
3: \text { 4-benzpyrene (synthetic) } \\
\text { Cholanthrene } \ldots \\
\text { 10-methyl-1 : 2-benzanthra- } \\
\text { cene } \\
3: 4: 8: 9 \text {-dibenzpyrene } . \\
1: 2: 5: 6 \text {-dibenzanthracene } \\
1: 2: 5: \text { 6-dibenzacridine }\end{array}$ & & $\begin{array}{r}43 \\
99 \\
151 \\
\\
127 \\
109 \\
112 \\
\\
147 \\
205 \\
239 \\
350\end{array}$ & $\begin{array}{c}13 / 20 \\
18 / 18 \\
5 / 8 \\
\\
10 / 10 \\
7 / 9 \\
28 / 49 \\
\\
12 / 18 \\
10 / 17 \\
41 / 65 \\
6 / 25\end{array}$ \\
\hline
\end{tabular}

* Numerator $=$ tumour mice ; denominator $=$ total mice.

Other Aromatic Condensed Ring Compounds.-To some degree the benzanthracene story was repeated with other aromatic condensed ring compounds. Thus chrysene, phenanthrene, fluorene, and even anthracene turned out to be the inactive parent hydrocarbon of carcinogenic derivatives, which were synthesised by introducing methyl groups or additional benz- or penta-rings into the molecule. Thus 1:2-dimethylchrysene (fig. 9), 3:4-benz- phenanthrene (fig. 10), $1: 2: 5: 6$-dibenzfluorene (fig. 11), $9: 10$-dimethylanthracene (fig. 12), and $5:$ 10-dimethylene $1: 2$-cyclopentenoanthracene (fig. 13) all showed carcinogenic potency,

TABLE 2

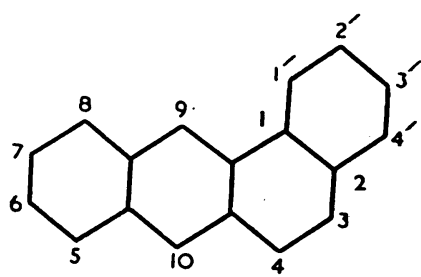

TUMOUR PRODUCTION IN MICE (METHYL DERIVATIVES OF 1 : 2-BENZANTHRACENE): TABLE SHOWING EFFECT OF MINOR ALTERATIONS IN MOLECULAR STRUCTURE ON CARCINOGENIC POTENCY

\begin{tabular}{|c|c|c|}
\hline & $\begin{array}{c}\text { Skin } \\
\text { application* }\end{array}$ & $\begin{array}{l}\text { Subcutaneous } \\
\text { application* }\end{array}$ \\
\hline $\begin{array}{c}\text { 1'-methyl } \\
\text { 2'-methyl } \\
\text { 3'-methyl } \\
\text { 3-methyl } \\
\text { 4-methyl } \\
\text { 5-methyl } \\
\text { 6-methyl } \\
\text { 7-methyl } \\
\text { 8-methyl } \\
\text { 9-methyl } \\
\text { 10-methyl }\end{array}$ & $\begin{array}{l}0 \\
0 \\
0 \\
0 \\
1 / 10 \\
5 / 10 \\
3 / 10 \\
0 \\
? \\
3 / 20 \\
11 / 20\end{array}$ & $\begin{array}{c}\because \\
\because \\
\ddot{1} \\
1 \dddot{7} / 20 \\
\ddot{1} / 19 \\
1 \ddot{7} / 20 \\
26 / 30\end{array}$ \\
\hline
\end{tabular}

- Numerator=tumour mice ; denominator $=$ total mice.

\section{TABLE 3}

TABLE SHOWING EFFECT ON CARCINOGENIC POTENCY OF PROGRESSIVE DILUTION OF THE DOSE OF CARCINOGEN (SUBCUTANEOUS INJECTION)

\begin{tabular}{l|c|c|c|c}
\hline $\begin{array}{c}\text { mg. 1:2:5:6- } \\
\text { dibenzan- } \\
\text { thracene }\end{array}$ & $\begin{array}{c}\text { No. of } \\
\text { mice }\end{array}$ & $\begin{array}{c}\text { Tumour } \\
\text { mice }\end{array}$ & $\begin{array}{c}\text { Tumours } \\
\text { per cent. }\end{array}$ & $\begin{array}{c}\text { Mean } \\
\text { latent } \\
\text { period- } \\
\text { months }\end{array}$ \\
\hline 0.01 & 328 & 37 & 11 & $\ldots$ \\
0.005 & 364 & 13 & 4 & $\ldots$ \\
0.0025 & 167 & 2 & $1 \cdot 2$ & $\ldots$ \\
0 C0125 & 158 & - & - & $\cdots$ \\
\hline 5.0 & 10 & 5 & 50 & $4 \cdot 3$ \\
$2 \cdot 5$ & 10 & 8 & 80 & $3 \cdot 8$ \\
1.0 & 10 & 9 & 90 & $3 \cdot 6$ \\
0.5 & 10 & 10 & 100 & $3 \cdot 6$ \\
025 & 30 & 26 & 90 & $4 \cdot 6$ \\
0125 & 20 & 9 & 45 & 6 \\
0.05 & 10 & 4 & 40 & $7 \cdot 3$ \\
00125 & 20 & 4 & 20 & 8 \\
0065 & 20 & - & - & - \\
\hline
\end{tabular}


<smiles>Cc1c(C)c2c3ccccc3ccc2c2ccccc12</smiles>

FIG. 9.-1 : 2-dimethylchrysene.<smiles>c1ccc2c(c1)ccc1ccc3ccccc3c12</smiles>

Fig. 10.-3 : 4-benzphenanthrene.<smiles>c1ccc2c(c1)Cc1c-2ccc2ccccc12</smiles>

FIo. 11.-1 $: 2: 5: 6$-dibenzfluorene.<smiles>Cc1c2ccccc2c(C)c2ccccc12</smiles>

Fig. 12. $-9:$ 10-dimethylanthracene.<smiles>c1cc2c3c(cccc3c1)CC2</smiles>

FIG. 13.-5 : 10-dimethylene 1 : 2-cyclopentenoanthracene.

One particular hydrocarbon, 20-methylcholanthrene (figs. 14 and 16) is especially interesting. Cook<smiles>Cc1ccc2cc3c(ccc4ccccc43)c3c2c1CC3</smiles>

Fio. 14.-20-methylcholanthrene (a).

(1933) had found that positions 5- and 6- in the $1: 2-$ benzanthracene molecule were of importance in that substitution there conferred carcinogenicity, and that, secondly, the addition of a penta-ring in that position would give a hydrocarbon which was not only a benzanthracene derivative but which could also be considered as a ring-closed and dehydrogenated derivative of deoxycholic àcid (fig. 15).

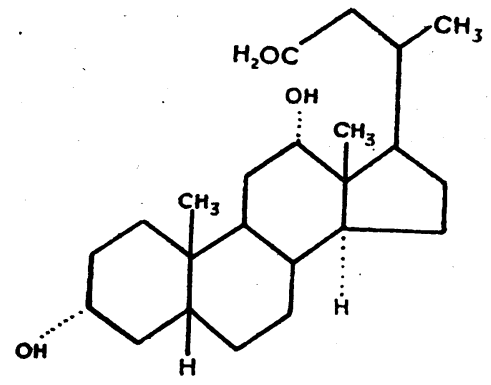

FIG. 15.-Deoxycholic acid.<smiles></smiles>

FiG. 16.-20-methylcholanthrene (b).

Methylcholanthrene was made from cholic acid and also synthetically, and its powerful cancerproducing activity was useful evidence for the protagonists of the hypothesis that spontaneous human cancer is caused by the operation of endogenic carcinogens derived from sterols, a hypothesis which still awaits proof.

Nitrogen and Sulphur Analogues of Polycyclic Hydrocarbons. - Besides the polycyclic hydrocarbon carcinogens, there are their nitrogen and sulphur analogues such as dibenzacridine (fig. 17), dibenz- 
carbazole (fig. 18), and a thiophene-substituted 1:2-benzanthracene derivative (fig. 19), all of which - are carcinogenic.<smiles>c1ccc2c3c(ccc2c1)-c1nc2c(ccc4ccccc42)cc1-3</smiles>

FIG. 17.-1 $: 2: 5$ : 6-dibenzacridine.<smiles>c1ccc2c(c1)ccc1[nH]c3ccc4ccccc4c3c12</smiles>

FIG. 18.-1 $: 2: 5:$ 6-dibenzcarbazole.<smiles>Cc1c2sc3ccccc3c2c(C)c2ccc3ccccc3c12</smiles>

FIG. 19.-4 : 9-dimethyl-2 : 3 : $5: 6$ - dibenzthiophanthrene.

Simpler carcinogens are known, examples of which are 2-anthramine (fig. 20) and 2-acetylaminofluorene (fig. 21), and a further step away from the<smiles>Nc1ccc2cc3ccccc3cc2c1</smiles>

FIG. 20.-2-anthramine.<smiles>CC(=O)Nc1ccc2c(c1)Cc1ccccc1-2</smiles>

FIG. 21.-2-acetylaminofluorene.

original type of carcinogenic hydrocarbon is shown by the structure of the active liver-cancer-producing azo dyes, the best known example being butter yellow, 4-dimethylaminoazobenzene (fig. 22). The<smiles>CN(C)c1ccc(N=Nc2ccccc2)cc1</smiles>

FIG. 22.-4-dimethylaminoazobenzene (" butter yellow").

aminostilbenes, for example 4-dimethylaminostilbene (fig. 23), which can be regarded as analogues<smiles>CN(C)c1ccc(C=Cc2ccccc2)cc1</smiles>

FIG. 23.-4-dimethylaminostilbene.

of the azo dyes, were found to be carcinogenic by Haddow in the course of his work on growth inhibition by carcinogenic hydrocarbons. This compound, and also 2-anthramine and 2-acetylaminofluorene, have the peculiarity of producing tumours in the rat in a considerable variety of tissues in the body as well as at the site of injection.

\section{Physical Methods of Investigating Carcinogenic Hydrocarbons}

The discovery of the carcinogenic hydrocarbons and the isolation of $3: 4$-benzpyrene from pitch was largely due to the fortunate circumstance that the intense fluorescence of the hydrocarbon is highly characteristic and that it is able to overcome the combined fluorescences of the hundreds of other compounds present in that complex mixture. Naturally, fluorescence spectroscopy, first applied by Mayneord and exploited by Hieger, has been the principal physical method used in the study of carcinogenic hydrocarbons.

Berenblum has demonstrated that by using a moving wedge technique a more quantitative measure of the characteristics of the fluorescence spectrum can be obtained to assist in the identification of fluorescent derivatives of hydrocarbons, and a similar refinement has been developed by Holiday for absorption spectroscopy. These two methods have been employed to check identity and to estimate hydrocarbons quantitatively, for example, the disappearance rate when they are applied to the skin or injected into animals.

An interesting calculation shows that $10^{-1} \mu \mathrm{g}$. benzpyrene per cell could be detected if use were made of the Caspersson method of micro-spectrography in monochromatic ultra-violet light. This quantity represents a rather high concentration of hydrocarbon, namely $2 \mu \mathrm{g}$. per mg. or $2 \mathrm{mg}$. per g. of tissue. The minimum quantity required for carcinogenesis is still uncertain for a number of rather obvious reasons. For example, 
after a hydrocarbon is injected, it can be quantitatively recovered after the tumour appears (Shear), suggesting that carcinogen is not used up in the carcinogenic process and that the rate of elimination has nothing to do with carcinogenesis but with the mechanisms which are anticarcinogenic, that is, the de-toxication and excretory apparatus.

"The dosage of hydrocarbon required to initiate a tumour is often, however, far lower than that used in these metabolic experiments, and it remains uncertain whether the fraction of the hydrocarbon which is instrumental in carcinogenesis follows the same metabolic path as the bulk of material. The minimal doses for carcinogenesis are probably too low for standard spectroscopic techniques to be applicable."

The absorption-technique will probably prove more useful than fluorescence in tracing the fate of minute amounts of carcinogens in the tissues, since a slight chemical change can extinguish the fluorescence while only moderately altering the absorption spectrum.

\section{Mode of Action of Chemical Carcinogens}

The first step in the attack on this baffling problem was, of course, to try to find some parallel between chemical structure and carcinogenic activity. Much has been written on this subject, but always en arriere ; that is, explanations have been put forward<smiles>Cc1c2ccccc2c(C)c2c(C)c3ccccc3c(C)c12</smiles>

FIG. 24.-9 : 10-dimethyl-1 : 2-benzanthracene.<smiles>CC1=c2c(C)c3c(c(C)c2C=C1)=C(C)c1ccccc1-3</smiles>

Fia. 25.-9 : 10-dimethyl-1 : $2: 7: 8$-dibenzanthracene.<smiles>Cc1c2ccccc2c(C)c2c3ccccc3c3ccccc3c12</smiles>

Fig. 26. -9 : 10-dimethyl-1 : $2: 3:$ 4-dibenzanthracene.

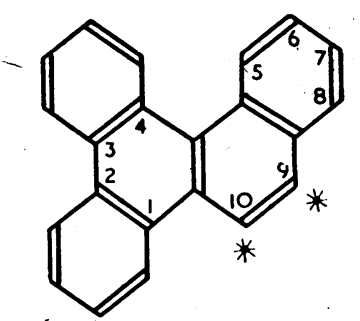

FIG. 27.-1 : $2: 3$ : 4-dibenzphenanthrene.<smiles>Cc1cc2c3ccccc3c3ccccc3c2c2ccccc12</smiles>

FIG. 28.-9-methyl-1 : $2: 3:$ 4-dibenzphenanthrene.<smiles>Cc1cc2ccccc2c2c3ccccc3c3ccccc3c12</smiles>

FIG. 29.-10-methyl-1: $2: 3:$ 4-dibenzphenanthrene. after the two properties had been found together, and the position has become more difficult as each new carcinogen is discovered. Haddow is careful to point out that none of these hypotheses are as yet satisfactory, either because sooner or latér exceptions are found to any generalization, or because it has not yet been possible to carry out an adequate test of their validity. To find a theory relating carcinogenic mechanism and chemical constitution which will embrace the structures of hundreds of carcinogens ranging from 4'-dimethylaminostilbene to $3: 4$-benzpyrene, from acetylaminofluorene to $1: 2: 5: 6$-dibenzanthracene, or from 430-styrol to urethane, presents a formidable task. For example, of the three benzanthracene derivatives, $9: 10$-dimethyl-1 : 2-benzanthracene (fig. 24), 9 : 10-dimethyl-1: $2: 7:$ 8-dibenzanthracene (fig. 25), and $9: 10$-dimethyl-1 $: 2: 3: 4$-dibenzanthracene (fig. 26), the first two are carcinogenic, and the third is inactive. This difference is explained by the absence of an essential phenanthrene double bond, shown by asterisks in the formulæ. Furthermore, of the three dibenzphenanthrenes, $1: 2: 3: 4$ - 
dibenzphenanthrene (fig. 27), 9-methyl-1 $: 2: 3: 4$ dibenzphenanthrene (fig. 28) and 10-methyl$1: 2: 3: 4$-dibenzphenanthrene (fig. 29), only the first is active ; again this difference is accounted for by the unsubstituted phenanthrene bond being absent in the 9-methyl and 10-methyl derivatives.

However, no explanation is offered of why 1:2-benzanthracene (fig. 3) is inactive but that substitution in the 3 or 4 position by methyl not only fails to interfere with the important phenanthrene double bond but actually confers carcinogenic activity on the parent hydrocarbon.

Physical Theory Applied to Carcinogenic Hydrocarbons.-Physical theory has been applied to the study of carcinogenic hydrocarbons by Schmidt (1924) and by Pullman (1945, 1946) and Daudel (1946), and it has been proposed that the electron density at the phenanthrene double-bond position in the benzanthracene molecule must be above a critical limit for carcinogenic potentiality to appear. The order of electron density in different compounds approximately corresponds with what would be expected from the order of biological potencies of a series of carcinogens.

The Pullman technique requires the solution of 2,000 simultaneous equations for obtaining a numerical value for characterizing the electron density, in a single compound ; consequently very few investigators are likely to undertake such a laborious task.

The terminology is highly technical :

"In the aminostilbenes it would seem to be a necessary condition, although clearly not a sufficient one, that the molecule should be capable of assuming a quinonoid disposition, with an electron-donating group in one ring conferring a high degree of negative polarity in the other and the outstanding feature being the necessity for unsubstituted hydrogen atoms in the ethylene bridge and at the $\mathrm{p}^{\prime}$ position. Such a system would appear not merely to contain a structure in the ethylene bridge which is analogous with the phenanthrene double bond in the cyclic hydrocarbons, but to possess electronic characters which are produced in condensed systems of benzene rings by rather different means."

". . a necessary condition of carcinogenic activity is that the density of such regions should exceed $0.44 \mathrm{e} / \mathrm{A}^{2}$; in particular, he further suggested that the activity of a carcinogen is due to the electro-affinity of its excited state facilitating a quantal change in neighbouring molecules. More recently $\mathbf{A}$. and $\mathbf{B}$. Pullman (1946) and Martin (1946) have obtained supporting evidence of this conception through a quantum mechanical treatment (with Daudel) which permits a calculation of the density of electrons for a given structure (in chrysenes, benzanthracenes, and benzacridines) by means of which it is claimed that a relation can be formulated between carcinogenicity and the electronic density of the region $K$, the densitythreshold below which a substance ceases to be carcinogenic being 1.292e."

However, as has been aptly pointed out, the test for any such theory relating structure and carcinogenic activity would be its capacity to assess the activity of a compound before and not after the biological test.

Order of Carcinogenic Potency:-Fieser has pointed out that the order of carcinogenic potency of the hydrocarbons is the same as the order for substitution reactivity in diazo coupling, oxidation with lead tetra-acetate, or perbenzoic acid, and condensation with sulphur monochloride. The awkward fact that some anthracene derivatives also show high reactivity is circumvented by the explanation that the carcinogen must also possess additional properties such as suitable solubility, adsorbability. and molecular size. He suggests that in the carcinogenic process the $\mathbf{S}$ - groups in tissue proteins I

are converted to the stiucture

$$
\left.\begin{array}{r}
\text { Hydrocarbon-S- } \\
\text { SH- }
\end{array}\right\} \text { proteide, }
$$

but only evidence by analogy is offered in support of this possibility.

Fieser found that the catalytic hydrogenation of methylcholanthrene resembles enzymic reactions and results in the addition of $\mathrm{H}_{2}$ at positions other than the centres usually accepted as the most reactive, that is the meso positions, and that this reaction is much slower than meso substitution. In the example given, methyl-cholanthrene adds an $\mathrm{H}_{2}$ at the reactive phenanthrene double-bond position if this hydrocarbon is considered structurally as a $1: 2$-benzanthracene derivative, which would be in agreement with the phenanthrene bond theory.

The metabolic products of hydrocarbons which can be isolated in feeding experiments on rats and rabbits (Boyland and Levi, 1935, 1936) shows that in vivo the points of attack are neither the reactive meso positfon nor the phenanthrene double bond (the $\mathrm{K}$ region) but the $4^{\prime} 8^{\prime}$ positions for $1: 2: 5: 6$ dibenzanthracene and the $4^{\prime}$ position for $1: 2$-benzanthracene, although there is little evidence that these metabolites represent more than a mere fraction of the total metabolic products.

Fieser is quoted as saying,

“. . the assumption that the metabolic change follows a fundamentally different reaction mechanism from the postulated substitution reaction of carcinogenesis seems necessary in order to account for the 
fact that the attack occurs at a part of the molecule different from that involved in substitutions."

The writer confesses to being somewhat puzzled by this quotation. It is surely unjustified to derive an " assumption" from a "postulation " based on a " fact" which is required to be proved.

Fieser suggests that, since substitution reactions bear an order-parallelism with carcinogenic potency, substitution is closely associated with the carcinogenic mechanism; but as meso-substituted 1 :2benzanthracene derivatives are the most powerful carcinogens, the carcinogenic substitution probably takes place elsewhere in the molecule, namely at the position of secondary reactivity, the phenanthrene double bond. Why, then, does substitution induce carcinogenic potency into the molecule? It can hardly be because the remaining $\mathrm{H}$ atom is specially activated for the substitution reaction, for if either of the $\mathbf{H}$ atoms in the phenanthrene double bond of $1: 2: 3: 4$-dibenzphenanthrene is substituted by $\mathrm{CH}_{3}$ the carcinogenic potency disappears.

Sulphur-linkage.-Crabtree also considers that the sulphur linkage is the point of attachment of the carcinogen, to the tissue components, because compounds which competitively attach themselves to S-groupings inhibit carcinogenesis by hydrocarbons. These inhibitors include brombenzene and the simpler polycyclic aromatic hydrocarbons, anthracene, phenanthrene, and naphthalene. If this explanation were true one would then have to explain why tar, which is the source of all these simple hydrocarbons, is carcinogenic. Assuming that the carcinogen is attached to a tissue component by a S-linkage, one is tempted to ask, what happens next?

Biological Aspects of Carcinogenesis.-With regard to the biological aspect of carcinogenesis, Haddow proposed that the process is set in motion by the inhibition of the growth of normal cells finally leading to the domination of the tissue by those cells which have successfully adapted themselves to the new conditions. Some of the cells are immune to the inhibitory action of the carcinogen.

It would be interesting to know, and such experiments have probably been tried, if local injection can be influenced by simultaneous remote treatment.

The adapted strain of cells is supposed to be a mutant form of normal cells, an explanation of cancerous change which is nearly as old as the mutation theory itself; but, until cancer cells can be crossbred, evidence for mutation theory in cancer cannot be completely satisfactory.

Haddow draws on analogies with experiments on strains of Neurospora, where mutations are induced by variations in the available amino acid supply, but it might perhaps be objected that one of the most powerful mutagens (mustard gas) is an anticarcinogen. In favour of the mutation theory for carcinogenesis is the discovery of Strong that the descendants of mice treated with methyl-cholanthrene become mutated for coat colour and for incidence of spontaneous gastric cancer, and secondly, Demerec has found that the carcinogens are also potent mutagens for Drosophila. Carcinogens, ultra-violet light, $x$ rays, and raised temperature all facilitate mutations in Drosophila, and all these agents have carcinogenic capacity for mammalian and avian tissues.

Haddow then embarks on a somewhat daring theory of carcinogenesis. Schrödinger, in his book What is life? describes a gene mutation as the product of a quantum jump in the gene molecule resulting in a new gene possessing an altered configuration. The problem of mutation thus is reduced to the question, how is the energy to be supplied to the electrons of the gene molecule to make them jump?

The answer is, by radiation (that is, carcinogenic radiation) or by the energy liberated during the chemical transformations which are undergone by the carcinogen in changing to its metabolic derivatives. Again, until evidence is forthcoming, such speculation-however attractive-must remain purely imagination, for notwithstanding the great beauty of Schrödinger's exposition, its application to chemical carcinogenesis depends in the first place on the adequacy of a further theory, that carcinogenic transformation is indeed a mutation.

By analogy with the discoveries of Sonneborn on cytoplasmic inheritance in Paramicium, Haddow propounds the hypothesis that virus tumours contain the controlling mutagen, that is the virus, in the cytoplasm as a cytogene or plasmagene (anything but a nuclear-gene). From this description of the conditions in virus tumours it is but a step to the idea that in mammalian tumours not transmissible by filterable viruses similar mutagens in the form of autosynthetic proteins or enzymes form a more labile and integrated part of the tumour cell such that attempts at separation in these cases by the crude methods now available destroy the mutagenic structures. To complete the edifice of theories one further idea is necessary, that the chemical carcinogen causes some selfduplicatory protein in the normal cell to mutate to a " 'rogue' enzyme upon which the newly acquired growth-properties may possibly depend," and it is only required to substitute "mutated gene" for "rogue enzyme." 


\section{Co-Carcinogenesis}

Co-carcinogenesis is defined by Berenblum as " augmentation of tumour production resulting from a direct local effect on a tissue," to distinguish it from $(a)$ promoting effects induced by alteration in the diet in experimental liver tumours induced by dimethylaminoazobenzene, called " pro-carcinogenic " effects, and from $(b)$ the effects of the solvent on a carcinogenic hydrocarbon in situ, where alteration in the vehicle probably alters the elimination rate of the agent.

The earliest experimental co-carcinogenic agencies were wound healing, freezing with carbon-dioxide snow, mechanical irritation, subcutaneous fibrosis, radiation of all kinds, the basic fraction of creosote oil and-most effective of all-croton oil. Chemical irritants are by no means always co-carcinogens and even the members of the above list must be applied in suitable doses for their effects to be detected. Berenblum has concluded from the data of experiments with co-carcinogens that the carcinogenic process proceeds by stages : (1) pre-carcinogenesis, where some fundamental change is brought about in normal cells preparing them for the second stage ; (2) epicarcinogenesis, the actual conversion to neoplasia ; and (3) metacarcinogenesis, the transformation of benign growths to malignant tumours.

Carcinogens proper can carry out all three stages but co-carcinogens can only carry out stages 2 and 3 . Thus he has found that a single application of a carcinogen will irreversibly convert some cells in mouse skin to the preneoplastic condition; all the subsequent changes can at any later time be effected by croton oil. The phenomenon has been clearly observed by Rous and Kidd (1941) in the tarring of rabbits, where the warts are very liable to regress and require co-carcinogens (wound healing, further tarring, application of chloroform or turpentine) for the growth of the warts to be maintained. Rous proposes that the first change in the normal cells be termed "initiation" (Berenblum's pre-carcinogenesis") and that the second stage be called the "promoting" process (Berenblum's " epi-carcinogenesis ").

It has been found that if a carcinogenic hydrocarbon is applied once to the skin of a mouse, which is then left untreated for twenty weeks, the application of croton oil will then bring about tumour formation. Since hydrocarbon can no longer be detected after a very few weeks, and since the turnover rate of the cells in the skin must also contribute to the removal of the original effects of carcinogen, it follows that the pre-carcinogenic cells must be self-duplicating so as to leave-behind some cells that are ready for epi-carcinogenesis. In other words, one painting with carcinogen rapidly 'mutates' some skin cells to the pre-carcinogenic state, or, one treatment with carcinogen permanently alters the skin.

Although Berenblum can show the co-carcinogenic effect by demonstrating a great increase in the total number of tumours evoked by diluted carcinogenic hydrocarbons and by revealing irreversible changes in cells which have been converted into potential tumour cells, no experiments have yet succeeded in showing co-carcinogenic action to be capable of raising the carcinogenic potency of feeble or slow-acting carcinogens.

\section{Anti-Carcinogenesis}

Crabtree in his article on anti-carcinogenesis gives a list of the agents for which inhibitory action has been claimed: "Mustard gas and a few of its oxidized and substituted derivatives, cantharidin, carbon-dioxide snow, heptaldehyde, a phenolic fraction of tar, simple substances containing a labile halogen atom, p-thiocresol, strong sunlight and organic peroxides, acid chlorides, the mercapturate forming hydrocarbons, naphthalene, anthracene, and phenanthrene."

It should be noted that two of the agents in this list are known to be also cancer producers and further, when the inhibition tests were repeated by other workers, in some cases it was impossible to obtain confirmation of earlier results, which was probably due to differences in the conditions under which the agents were tested and also to variations in the biological material.

Experiments on a series of chlorine-containing compounds has shown that a relation exists between their efficiency as inhibitors both of tumour induction and of tissue glycolysis ; they probably operate via hydrochloric acid liberation by hydrolysis, for the order of lability of the chlorine was the same as the order of inhibitory power.

The halogen compounds can also act directly by condensing with SH-containing cell components, thus impairing the efficiency of those enzyme systems dependent on intact SH-groups for their proper functioning; examples of this type of inhibitor are brombenzene, maleic and citraconic acids, heptaldehyde, and mercapturate-forming hydrocarbons. All these compounds deplete the skin of glutathione and are antagonistic to cancer production in the skin, and Crabtree therefore puts forward the speculation that some reaction between carcinogen and SH- grouping of constituents of tissues is essential for tumour induction.

$\mathrm{He}$ is, however, careful to point out the tentative nature of these speculations by the plentiful use of that overworked word "may." 
"The work of Weigert and Mottram (1946) on the metabolism of 3:4-benzpyrene, by the aid of fluorescence spectra, has shown that a series of intermediate compounds can be identified between the hydrocarbon itself and the final oxidized derivatives which are excreted. These intermediates contain radicals derived from unknown cellconstituents, and may conceivably represent the true carcinogens. The coupling may well involve SH-groups, and recalls the surmise of Wood and Fieser (1940), based on considerations of the special chemistry of $3: 4$-benzpyrene, that such a fixation may be an initial stage in the carcinogenic process."

The induction of liver tumours in the rat and mouse by feeding $4^{\prime}$-amino-2:3'-azotoluene or $\mathbf{N}: \mathbf{N}$-dimethyl-p-aminoazo-benzene, can be inhibited by alterations in the diet. This inhibition or rather protective effect is shown by substituting wheat, rye, or millet by rice bran, yeast, liver, casein, and riboflavin, casein and B vitamins, or by dried whole milk and carrot, but biotin stimulates livertumour production by azo dyes.

The metabolic oxidative products of the azo dyes are inhibitory for a number of enzyme systems, and it has been suggested that the dye acts carcinogenically via an oxidized product which attacks the SH-group of the enzyme. It is a little difficult to reconcile this hypothesis with the non-carcinogenicity of the oxidized end products, but perhaps no more difficult than to explain why tar should be carcinogenic, since it is full of mercapturateforming hydrocarbons like anthracene, phenanthrene, and naphthalene which Crabtree and also Lacassagne have reported to inhibit tumour production by the carcinogenic hydrocarbons. Crabtree refers to the notable work of Tannenbaum who found that animals on a diet deficient in calories show inhibition of spontaneous and artificially induced cancer. Animals on such diets are stunted and have atrophic endocrine systems, which would account for the failure to develop breast cancer.

\section{The Influence of the Solvent on the Carcinogenic Response}

Dickens describes the effect of solvent on the rate of appearance and total number of tumours produced when benzpyrene in solution in a variety of solvents is injected subcutaneously into mice.

The effect of varying the solvent has been investigated by a number of workers, the majority agreeing that carcinogens dissolved in the fat of the same species as the animal undergoing injection show decreased potency, while oils such as arachis and olive oil increase the potency, as also does the addition of cholesterol. If the solution of carcinogen is painted on the skin instead of being injected, results sometimes occur showing the opposite effects.

Dickens uses as standard technique $0.3 \mathrm{mg}$. benzpyrene dissolved in $0 \cdot 3 \mathrm{c.cm}$. tricaprylin injected subcutaneously into pure-strain mice; he rightly points out that the use of more carcinogen than is necessary for an optimal yield of tumour will only mask any inhibitory effect.

The decrease of carcinogenic efficiency when the hydrocarbon is dissolved in mouse fat has been confirmed, and purification of the fat indicated that the fraction possessing inhibitory powers is concentrated in the phospholipid part which can be removed by extraction with acetone.

Addition of 3 per cent. cholesterol to the tricaprylin solution of benzpyrene raised the total of tumours from about 45 per cent. to over 80 per cent. ; $0.3 \mathrm{c} . \mathrm{cm}$. ox-brain lipids containing $0.3 \mathrm{mg}$. benzpyrene gave only one tumour in twenty-nine mice. Ox-brain lipids were the most potent inhibitors, followed by fresh mouse fat, then by mouse fat freed from phospholipids by acetone, which when used as solvent for benzpyrene gave a yield of tumours differing only slightly from the controls injected with benzpyrene in tricaprylin. Two phospholipids (cephalin and lecithin) had only a moderately retarding effect on the development of tumours, which suggests that either fresh mouse fat must contain some other inhibitor, or the phospholipids are present in some peculiar state.

Estimation of hydrocarbon in whole animals at different times after injection showed that mice which had received solutions containing cholesterol (that is, the most efficient tumour producers) had eliminated the hydrocarbon much the most rapidly (from $0.3 \mathrm{mg}$. only $0.001 \mathrm{mg}$. was left in 82 days), while the animals injected with the less effectively carcinogenic solutions containing hydrocarbon plus lecithin and cephalin retained hydrocarbon for a much longer period (from $0.3 \mathrm{mg}$., $0.065 \mathrm{mg}$. was left in 82 days).

Such a result is unexpected particularly if it be noted that the first of the twenty-three tumours in the cholesterol series did not appear until the seventieth day, when more than 99 per cent. of the hydrocarbon had already been eliminated. Dickens suggests that these data support the metabolite theory of carcinogenesis, which postulates that the hydrocarbon has first to be converted to a derivative, the true carcinogen ; he proposes that the phospholipids behave as' anti-oxidants by retarding the conversion to the effective carcinogenic agent. The anti-oxidation effect on hydrocarbons of phospholipids could be confirmed in vitro ; but cholesterol, which would be expected to show pro-oxidation properties in line with its capacity for tumour 
facilitation, showed no acceleration of oxidation in vitro.

Hydrocarbons when dissolved in purines disappear very rapidly on injection, but low incidences of tumours result ; hence, Dickens concludes that a distinction must be made between physical and chemical elinination of carcinogen and that the tumour inhibitory solvents act by retarding the oxidation of the hydrocarbon.

\section{Metabolism of Carcinogenic Compounds}

Boyland and Weigert's article on the metabolic products of the carcinogenic hydrocarbons is aimed at the elucidation of the mechanism of carcinogenesis by the theory that the true carcinogen is not the hydrocarbon itself but is a metabolite or is the energy liberated in the process of metabolism.

The evidence brought together here in favour of the theory rests on a number of facts, inferences, and analogies. Since the hydrocarbons are insoluble in water, the formation of water-soluble derivatives is required for a water-phase reaction (the possibility of an oil-phase reaction is also mentioned). It might be asked whether the oilsoluble hormones and vitamins have also to be converted to water soluble derivatives for activation.

One of the main supports for the metabolite theory is the fact that $1: 2: 5: 6$-dibenzanthracene is almost devoid of carcinogenic effect in one species, the rabbit, but is very potent in the tissues of the rat, and pari passu the metabolism of the hydrocarbon is different in the two species. Moreover, differences are also found in the metabolic products of anthracene when it is fed to the rabbit or to the rat.

The hypothesis is advanced that the rat converts $1: 2: 5: 6$-dibenzanthracene to a carcinogenic product but the rabbit transforms it to a non-carcinogenic metabolite, or alternatively that the route taken by the hydrocarbon in metabolism is different in the two species, emphasis being laid on the process rather than on the end product.

The theory is not entirely satisfactory for a number of reasons. For example, of the total amount of hydrocarbon administered to the animal, but a mere fraction can be isolated as metabolites of recognizable identity. The fate of the major part of the carcinogen and the chemical constitution of the metabolic products is still undefined. 3:4Benzpyrene when fed to rats or rabbits is excreted as the same two hydroxy derivatives, 8- and 10benzpyrols, but in different proportions, yet benzpyrene is highly carcinogenic for the rat but only very feebly so in the rabbit.

The majority of the metabolites are non-carcinogenic, and in the very few cases where a hydroxy derivative of a carcinogenic hydrocarbon is found to be carcinogenic its activity is lower than that of the parent hydrocarbon. When anthracene is fed or injected into rats or rabbits, water-soluble derivatives, chiefly the $1: 2$-dihydroxy-1 :2-dihydroanthracene, are excreted in the urine. A comparison of the melting points and optical rotation of the diol, its acetyl derivative and the glycuronide, shows that the metabolite from the rat and from the rabbit are different, but this difference can be accounted for by the explanation that the rat excretes the optically active diol and its derivatives, while the rabbit excretes the racemic forms. Whether the racemization takes place in vivo or in vitro has not yet been settled.

$1: 2$-Benzanthracene (almost inactive), and $9: 10$ benzanthracene (the most active carcinogen known) both yield the $4^{\prime}$ - hydroxy metabolite in rats and mice, suggesting that, in these cases at least, metabolism to a hydroxy derivative is merely a detoxication process, since both carcinogenic and noncarcinogenic hydrocarbons follow the same metabolic path.

From the urine of rats and mice that had been injected with $1: 2: 5: 6$-dibenzanthracene, $4^{\prime}: 8^{\prime}$ dihydroxy-1:2:5:6-dibenzanthracene was isolated ; the constitution of the analogous hydroxy derivative from rabbit's urine is still undecided.

A condensed account then follows of the intermediate stages between benzpyrene and the final metabolite, 8-benzpyrenol. Four substances $\left(X_{1} X_{2} F_{1} F_{2}\right)$ have been detected by their fluorescence and absorption spectra, in the tissues and excreta after the hydrocarbon has been painted on the skin or injected, or mixed with the diet.

The successive changes are represented in fig. 30 .

The authors' statement "In any case these experiments suggest that it is not the hydrocarbon itself which is the proximate carcinogenic agent but one of the metabolites $X_{1}$ or $F_{1}$ or the energy released during the transformation from $X_{1}$ to $F_{1}$," rests on the following data :

$F_{2}$ is 8-benzpyrenol, leaving $X_{1} X_{2}$ and $F_{1}$ to be dealt with. When the hydrocarbon is painted on mouse skin or injected, $X_{2}$ appears slowly and its development is increased by the application of fats which are inhibitory to tumour production (Dickens), and is reduced by croton oil, that is, a tumourfacilitating agent, hence $X_{\mathbf{2}}$ is not regarded as being involved in neoplastic transformation, leaving $X_{1}$ and $F_{1}$ to be considered.

No mention is made however, of any attempt to test the carcinogenicity of $X_{1}$ or $F_{1}$ although these two substances have been separated by Weigert and Mottram by chromatography; and, if their activity is at all comparable with that of benzpyrene, 


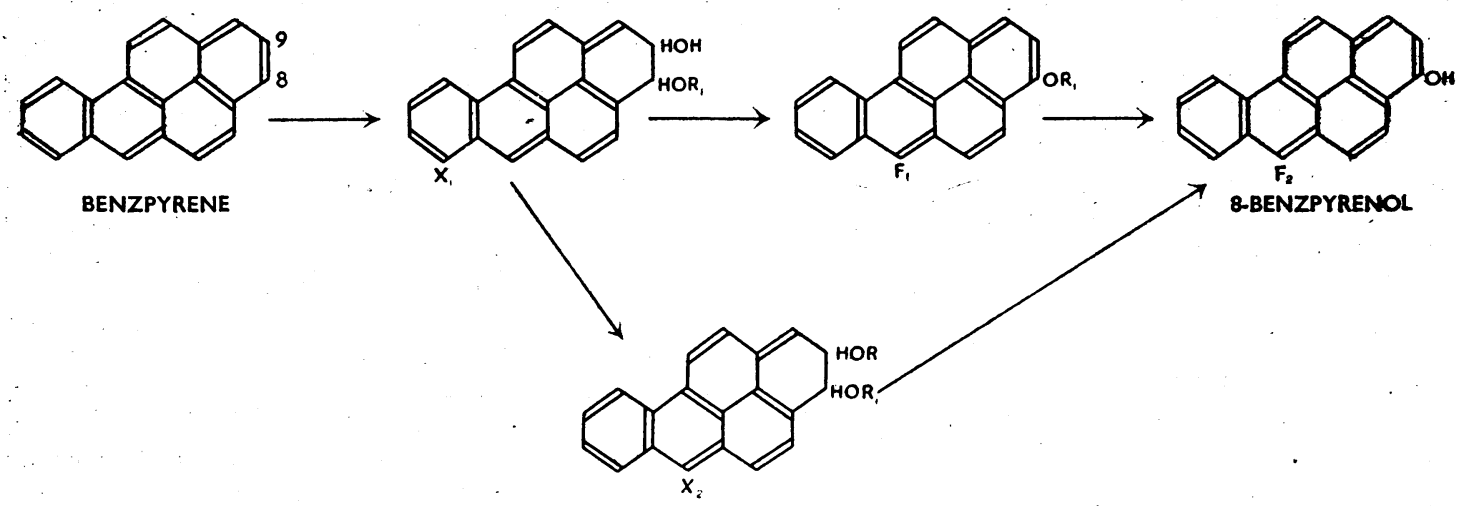

Fig. 30.-Successive changes from 3 : 4-benzpyrene to 8-benzpyrenol.

quite enough material should be obtainable from the skins of a number of mice which could be treated with the hydrocarbon and then extracted.

With regard to the carcinogenic process being dependent on the energy released during metabolism, that would be more difficult to test, but since anthracene and naphthalene undergo metabolic changes analogous to those of carcinogenic hydrocarbons, some carcinogenic energy should be released in all such transformations; nevertheless anthracene and naphthalene remain non-carcinogenic.

The metabolic products of butter yellow (pdimethylaminoazobenzene) inhibit the enzyme triose-phosphate-dehydrogenase, an essential enzyme in carbohydrate metabolism. Among these metabolites are p-phenylene diamine and $\mathrm{N}: \mathrm{N}$-dimethylp-phenylenediamine which are non-carcinogenic.

$\beta$-Naphthylamine induces bladder tumours in dogs and men but not readily in other species, and, in agreement with the authors' thesis, the metabolic end products are different in the dog and in rats, rabbits, and monkeys; the dog excretes the sulphate of 2-amino-1-naphthol, and the other species secrete 2 acetylamino-6-hydroxynaphthalene.

\section{Carcinogenic Substances in Human Tissues}

A number of workers have now confirmed Schabad's discovery in 1937 that a carcinogenic substance can be extracted from the tissues of cancerous human subjects. At first it was thought that only the liver contained the factor, but as more tissues were investigated it was found that livers from patients who had died of other diseases also contained the endogenic carcinogen, and further, that [it could be extracted from other organs besides the liver namely, lung, kidney, and muscle.

A difficult problem to be solved in the investigation of these substances is their apparent random occurrence ; for example, some livers yield potent carcinogenic extracts while others give inactive preparations. The randomness can also be explained by variations of susceptibility of the experimental mice which are injected with the extracts.

Schabad's first successes were with a crude benzene extract of liver of patients who had died of cancer; livers of non-cancerous subjects gave inactive extracts and saponification of cancer liver did not increase the potency of the preparation; in fact the unsaponifiable fraction of nine cancer livers was inactive.

Steiner $(1942,1943)$, who has done valuable work in this field, found on the other hand that crude extracts of liver were inactive but that unsaponifiable fractions were active. His best fractions gave twelve sarcomas at the site of injection in fifty-six mice; Schabad's active extract produced four sarcomas in one hundred and seventy-nine mice, one hundred and eight of which had survived eight months.

Unfortunately, neither in the experiments of Steiner nor of Schabad is it easy to find whether they tested the extracts, saponified and unsaponified, from the same livers in each case.

Menke's carcinogenic preparations were crude fatty extracts of human breast cancer; where the unsaponifiable fraction was tested it proved inactive but the experimental data do not indicate whether saponification does indeed concentrate the carcinogenic factor. In experiments on the isolation of the active substances, Hieger found on fractionation of the unsaponifiable fraction of human cancer liver and non-cancer liver, lung, or muscle, that the carcinogens were concentrated in that fraction which was richest in cholesterol (about 85 per cent. cholesterol).

It will be recalled that Dickens (Dickens and Weil-Malherbe, 1945) found that cholesterol acts as 


\section{CHEMICAL CARCINOGENESIS}

a tumour-promoter when it is added to a solution of a carcinogenic hydrocarbon, which would fit in well with some hypothesis such as : foreign fats are feebly carcinogenic when injected into sufficiently sensitive mice and the potency is increased in the presence of cholesterol. In the opinion of the writer, the investigation of feeble carcinogens will prove very difficult until some method is devised of overcoming the uncertainties due to inherent variations of susceptibility of the experimental animals. Until then it will be necessary to use large numbers of animals if it is attempted to make each group representative ; otherwise, contradictory results obtained in different laboratories can always be explained away by "susceptibility variations" of the experimental animals.

\section{Carcinogenic Action of Heated Fats and Lipoids}

Peacock's article is based on an examination of the thesis that the high incidence of gastric cancer in humans is due to a dietetic factor, namely the production of carcinogenic substances in food, especially fats, by overheating in the process of cooking, the critical temperature being in the region of $300^{\circ} \mathrm{C}$.

$\mathrm{He}$ cites Kennaway's experiments with $\mathrm{AlCl}_{3}$ and tetralin which reacts at $60^{\circ} \mathrm{C}$. to give a complex carcinogenic mixture of compounds. The activity is concentrated in the high boiling fraction when the mixture is distilled, but it is surely incorrect to suggest that distillation at $270^{\circ} \mathrm{C}$. yielded carcinogens which were not present in the undistilled mixture. The vivid fluorescence both before and after distillation is due to benzpyrene, which is concentrated in the high boiling fraction on distillation.

Peacock describes some interesting experiments where fowls were injected with dibenzanthracene in heated lard on one side of the body and with heated lard alone on the other ; 3 fowls developed tumours on both sides which suggested that dibenzanthracene was slowly removed from one side and stored up by the lard on the other side. No tumours resulted from the injection of heated lard alone into fowls. Burrows, Hieger, and Kennaway (1932) obtained twelve tumours, which were either sarcomas or fibromas, in 217 rats injected with lard alone. Much care was taken to reduce the chances of contamination by carcinogens; but even now, 17 years after the experiments were carried out, the question of contamination is not completely settled. Lard which had been heated to $350^{\circ} \mathrm{C}$. was also tested but the yield of tumours (two sarcomas) was, unfortunately for Peacock's thesis, reduced instead of increased by heating. It is not easy to interpret a passage in Peacock's paper dealing with "the minimal effective concentration of carcinogen," but probably what is meant is that carcinogen might be formed during overheating of fat but in amounts too small to be detected by biological methods. Recent work by the writer will throw a little light on the gloom surrounding the question of the minimum dose ; the record for the minimum is held by Shear, who produced a tumour in a mouse with $0.4 \gamma$ dibenzanthracene dissolved in cholesterol. Chlosterol has been regarded by most investigators as non-carcinogenic (although no one has yet reported the results of tests with the pure sterol); however, some doubt must now be cast on the non-carcinogenic reputation of commercial cholesterol and therefore the $0.4 \gamma$ must be multiplied an unknown number of times.

With regard to the feeding of overheated fats, Beck and Peacock (1941) induced gastro-papillomas but not carcinomas in rats fed with heated lard, although this condition can be brought about by a number of dietary deficiencies; and a somewhat similar conclusion was arrived at by Morris, Larsen, and Lippincott, who fed rats with a diet containing 50 per cent. of lard heated to $300^{\circ} \mathrm{F}$. for half an hour and found gastric ulcers and fatty degeneration of the liver.

The possibility of co-carcinogens promoting the effect of sub-threshold doses of carcinogen in the diet is still under consideration.

Peacock thinks it possible that the endogenic carcinogens are in part of exogenic origin and are found in the liver because they enter the body with the food and are carried along the metabolic route to be dissolved in the fat of the liver. There is certainly something attractive about this idea, for it would explain the haphazard distribution of liver carcinogens on individual dietetic differences, and also it would explain the age incidence of cancer since it would be expected that the carcinogen would gradually be accumulated during life. Against the theory is the fact that lung, kidney, and muscle of cancerous and non-cancerous subjects contain "endogenic" carcinogen, that the livers of newborn children contain it, and that in Europeans liver cancer is only about 1 per cent. of all carcinoma.

Peacock summarizes the experiments on the carcinogenicity of heated fats in a table (Table 4).

\section{Oestrogens and Neoplasia}

The extraordinarily interesting paper by Burrows and Horning suggests that the sex hormones form an essential part of the structure or mechanism or both, of numerous tissues of the body and that variations whether excess or deprivation upsets the normal development of the tissue. Whether the 
TABLE 4

PEACOCK'S SUMMARY OF EXPERIMENTS ON THE CARCINOGENICITY OF HEATED FATS

\begin{tabular}{|c|c|c|c|c|c|}
\hline Author & Substance & $\begin{array}{l}\text { Temperature and } \\
\text { time of heating }\end{array}$ & $\begin{array}{l}\text { Method of } \\
\text { administration }\end{array}$ & $\begin{array}{l}\text { Yield of } \\
\text { tumours* }\end{array}$ & $\begin{array}{l}\text { Nature of } \\
\text { tumour }\end{array}$ \\
\hline Beck (1941) & $\begin{array}{l}\text { Cotton-seed oil } \\
\text { Cotton-seed oil } \\
\text { Cotton-seed oil }\end{array}$ & $\begin{array}{l}340^{\circ}-360^{\circ} \text { C. } 1 \mathrm{hr} . \\
200^{\circ}-220^{\circ} \text { C. } 12 \mathrm{hrs} . \\
\text { Unheated }\end{array}$ & $\begin{array}{c}0.5 \mathrm{ml} \text {. } \\
\text { subcutaneously } \\
0.5 \mathrm{ml} \text {. } \\
\text { subcutaneously } \\
0.5 \mathrm{ml} \text {. } \\
\text { subcutaneously }\end{array}$ & $\begin{array}{l}\text { (12) } 2 / 6 \\
\text { (12) } 0 / 3 \\
\text { (12) } 0 / 10\end{array}$ & $\begin{array}{c}\text { Spindle-cell } \\
\text { sarcomas after } \\
414 \text { and } 538 \text { days } \\
- \\
-\end{array}$ \\
\hline $\begin{array}{l}\text { Beck, Kirby, } \\
\text { and Peacock } \\
\text { (1945) }\end{array}$ & $\begin{array}{c}20 \% \text { chlosterol } \\
\text { in olive oil or } \\
\text { cotton-seed oil } \\
20 \% \text { chlosterol in } \\
\text { cotton-seed oil } \\
\text { Residue from heated } \\
\text { cholesterol, } \\
20 \% \text { in olive oil } \\
20 \% \text { chlosterol } \\
\text { stearate in arachis oil } \\
25 \% \text { cholesterol } \\
\text { palmitate in } \\
\text { arachis oil } \\
25 \% \text { cholesterol } \\
\text { in arachis oil } \\
17 \% \text { cholesterol } \\
\text { in acetone }\end{array}$ & $\begin{array}{l}270^{\circ}-300^{\circ} \mathrm{C} . \frac{1}{2} \mathrm{hr} . \\
270^{\circ}-300^{\circ} \text { C. } \frac{1}{2} \mathrm{hr} . \\
270^{\circ}-300^{\circ} \text { C. } \frac{1}{2} \mathrm{hr} . \\
300^{\circ} \mathrm{C} . \quad \frac{1}{2} \mathrm{hr} . \\
300^{\circ} \mathrm{C} . \quad \frac{1}{2} \mathrm{hr} . \\
430^{\circ} \mathrm{C} . \quad \frac{1}{2} \mathrm{hr} . \\
430^{\circ} \mathrm{C} . \quad 1 \mathrm{hr} .\end{array}$ & 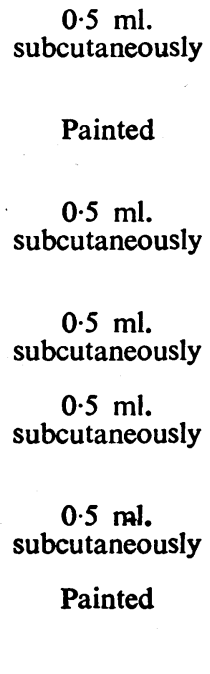 & $\begin{array}{l}\text { (18) } 1 / 8 \\
\text { (12) } 0 / 12 \\
\text { (12) } 1 / 11 \\
\text { (18) } 0 / 18 \\
\text { (24) } 0 / 24 \\
\text { (18) } 0 / 18 \\
\text { (18) } 3 / 4\end{array}$ & $\begin{array}{c}\text { Spindle-cell } \\
\text { sarcoma after } \\
386 \text { days } \\
- \\
\text { Spindle-cell } \\
\text { sarcoma after } \\
345 \text { days } \\
- \\
-\end{array}$ \\
\hline
\end{tabular}

* The num. ers in brackets give the initial numbers of mice under test. Fractions give the ratio of tumours to animals surviving at the time of the first tumour's appearance.

fate of these tissues is neoplastic change or not, the most obvious influences are to be found in the female generative system and in analogous tissues in the male.

The cells of the pituitary, the master organ of the body, respond to ostrogen by changes in the proportion of chromophile or chromophobe cells and may even become hyperplastic or adenomatous. Mice, rats, and other rodents treated for prolonged periods with oestrogen showed great enlargement of the pituitary; in Burrows' experiments the pituitary would sometimes occupy one-third of the cranial cavity. However, stoppage of the supply of œstrogen caused the pituitary gradually to resume its original size, and the overgrowth could be reversed or even inhibited from the beginning by the injection of thyrotropic hormone.

Artificial as well as natural œstrogens have been reported as stimulating different types of cells in the pituitary, and the various strains of mice react differently to equal doses of the hormone.
The hamster shows great sensitiveness to pituitary tumour promotion by @strogens, especially if thiourea is given simultaneously.

The ovaries had long been thought to play an important role in the development of breast cancer before experimental proof was obtained by prevention of the disease in mice by early ovariectomy and the re-establishment of the conditions for breast cancer by the injection of ostrogen, and moreover, by the incidence of Ereast cancer in male mice of liable strains by treatment with large doses of the hormone.

The genic factor in mammary cancer in the mouse has now given place in importance to extra-chromosomal influences and to the doninating effect of œitrogens. The maternal factor is transmitted in the milk but can be extracted from blood, spleen, and thymus ; and evidence continues to accumulate that it is a virus for it has the appropriate physical properties and it multiplies in the host from generation to generation. 
The experimental induction of uterine fibroids in mammals by œstrogens has been confirmed by many investigators. The guinea-pig is specially susceptible, and here ovariectomy hàd been reported as accelerating the appearance of the tumours ; in one series of experiments the latent period was only thirty-two days, and it has been shown that, just as in pituitary adenomata, regression occurs if the treatment is stopped, for example, by removing the pellets of œstrogen from the uterus.

The pituitary is not involved in the production of uterine tumours by œstrogen, for hypophysectomized guinea-pigs still respond to treatment with œstrogen; androgens or progesterone act as inhibitors to the ostrogen.

The results of clinical experience bear out laboratory tests on animals, for uterine fibroids, and functional menorrhagia are now known to be associated with a high level of œstrogen in the circulation. In human subjects öophorectomy or chemical inhibitors (testosterone) causes the tumours to regress. The authors emphasize that care must be taken with the administration of hormones affecting the uterine tissues, especially as malignant and benign tumours of the uterus sometimes react differently.

Carcinoma of the uterus in mice can be produced by œestrogens provided the appropriate strain is chosen for the experiment; Allen and Gardner (1941), working with the CBA strain or with CBAXC57 crosses, found that uterine carcinoma arose in over 50 per cent. of the animals by as low a dose as $16.6 \mathrm{\gamma}$ of estradiol benzoate given weekly.

The association of uterine adenoma and adenocarcinoma with other lesions known to be due to excessive ostrogen activity, for example, fibroids, polypoid adenoma, endometrial hyperplasia, and carcinoma-which are sometimes all found in the same patient-suggest that the same cause is responsible.

Oestrogens acting on the testis in mice cause hyperplasia of the Leydig tissue, particularly in Strong A strain mice, and finally evoke interstitial testicular tumours.

The two types of tissue in the prostate are differently stimulated by the sex hormones; excess œstrogen causes hyperplasia of the fibromuscular stroma in the prostate of the guinea-pig and atrophy of the secretory elements, which can be checked or prevented by progesterone, desoxycorticosterone, or testosterone. Thus the benign enlargement of the prostate in elderly men is thought to be due to a decline in the secretion of the inhibitory sex hormones relative to the supply of œstrogen.

After it had been observed clinically that an excess of cestrogen and androgen was excreted in the urine of patients suffering from adrenal tumours, Wooley, Fekete, and Little (1939) experimentally obtained nodular hypertrophy of the adrenal cortex by ovariectomizing mice; Gardner found 80 per cent. of adrenal cortical tumours in ovariectomized mice of the NH strain.

The CE strain of mice is highly susceptible to adrenal tumours, for 100 per cent. develop adrenal carcinoma after ovariectomy or castration shortly after birth. The tumour-bearing mice show all the histological changes in the accessory sex organs characteristic of prolonged stimulation with óstrogen, and it has been suggested that the adrenal in these cases is attempting to compensate for the loss of the gonads by over-production of hormone.

Local sarcomata, both spindle-celled and roundcelled, have been obtained by several investigators who repeatedly injected mice and rats subcutaneously with oestrogens. The carcinogenic potency is of course much lower than that of the hydrocarbons, but there is little doubt that it can be demonstrated. Lacassagne has reported a very high percentage of local sarcoma in mice injected with testosterone.

The carcinogenic hydrocarbons show slight œstrogenic activity, and from this fact it is deduced that the two properties overlap, but of course the œestrogens are hundreds if not thousands of times more potent than the hydrocarbons and to speak of overlapping is somewhat academic.

Oestrogens are now thought to play an important part in the induction of leukæmic conditions in the mouse; Gardner and others $(1940,1944)$ have increased the incidence of lymphoid tumours in a low leukæmic strain of mouse from 2 per cent. to 25 per cent. by $œ$ strogen administration, and have found evidence of the antagonistic action of androgen and œstrogen،

Some interesting experiments of Dmochowski and Horning indicate that the induction of leukæmia and of mammary cancer in the mouse show certain similarities in that a long latent period can elapse between treatment with ostrogen, which rapidly produces some permanent change in lymphoid or mammary tissue, and the development, several months later, of neoplastic changes.

To add to the catalogue of the biological activities of cestrogens, it has been found that they cause new bone formation on injection into immature female rodents; the medullary cavities of the long tones may become almost solid and there has been observed a sex incidence of tone tumours in liable strains of mice, where 77 per cent. of the tumours occur in the females and 29 per cent. in the males and at a later stage. 
The formula of some compounds of interest in this field are shown in fig. 31 .

\section{Carcinogenic Action of Stilbene Derivatives}

The theme of Dodds' short article is that, for compounds consisting of condensed benzene rings,
All were tested by "the standard method" for carcinogenic action, that is, by painting on the skin of the mouse. Surely another procedure, namely subcutaneous injection, can equally be called the standard method and in many ways it is more sensitive and precise than dabbing a drop of solution<smiles>CC12CCC3c4ccc(O)cc4CCC3C1CCC2=O</smiles><smiles>CC12CCC(=O)C=C1CCC1C2CCC2(C)C(O)CCC12</smiles><smiles>Oc1ccc(I)cc1</smiles>

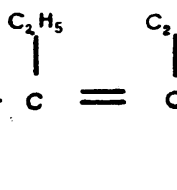<smiles>Cc1ccc(O)cc1</smiles>

FIG. 31.-Oestrone (left); testosterone (centre); stilboestrol (right).

analogues exist with similar biological activity but with the difference that some of the rings are opened and substituted by short chains ; by a little adjustment on paper the rings can be re-constituted to give back the polycyclic aromatic compounds.

As the leading example of the idea (" merely a hypothesis ") the structure of œstrone and stilboestrol<smiles>CC12CCC3c4ccc(O)cc4CCC3C1CCC2=O</smiles>

Fig. 32.-Oestrone.<smiles>CCC(=C(CC)c1ccc(O)cc1)c1ccc(O)cc1</smiles>

Fig. 33.-Stilboestrol.

are given in figs. 32,33 . The formulæ show that to pass from œstrone to stilboestrol would necessitate (1) introduction of an ethylene bridge ; (2) removal of $\mathrm{CH}_{3}$; (3) substitution of an aromatic benzene ring for a substituted penta ring ; and (4) opening of the two closed rings.

Six compounds containing open rings have been tested which show a close relation, on paper, to the best known carcinogens ; for example, for benzpyrene, the analogue was $\alpha$-ethyl- $\beta$-sec-butylstilbene (figs. 34,35 ), and similarly for $1: 2: 5: 6$ dibenzanthracene ; for $3:$ 4-benzphenanthrene, etc. on approximately the same site of a somewhat restless mouse.

Of six analogues tested on 350 mice, only one compound produced tumours ( $\alpha$-ethyl- $\beta$-secbutylstilbene) in two mice, and the tumours are described as a spindle-celled carcinoma and a spindle-celled sarcoma, which suggests that the<smiles>c1ccc2c(c1)cc1ccc3cccc4ccc2c1c34</smiles>

Fig. 34.-3 : 4-Benzpyrene.<smiles>c1ccc2c(c1)CCC1CC3C(=C21)CCc1ccccc13</smiles>

FIG. 35. $-\alpha$-ethyl- $\beta$-sec-butylstilbene.

carcinogen might have given more positive results if the test had been made on connective tissue.

The last paragraph of Dodds' article runs :

"In conclusion, it would appear that these substances have little interest from the point of view of experimental cancer production, since the experimenter has the choice of a large number of compounds of an infinitely greater potency. The interest in them is therefore purely theoretical, in that it does seem to support the hypothesis that simple analogues can be prepared for a number of the complex condensed carbon-ring compounds, including the carcinogens." 
However, since the experimental data show that open-ring analogues do not exhibit the biological activities of closed-ring hydrocarbons, by inference stilboestrol is œestrogenic not because it is an analogue of ostrone but for some unknown reason.

\section{Experimental Cancer of the Bladder}

Bonser's survey of cancer of the bladder begins with an account of the repeated attempts to reproduce in the laboratory the disease occurring in workmen in the dye industry; where they are exposed to dye intermediates like aniline, $\alpha$-and $\beta$ naphthylamine, and tenzidine.

Hueper and others (1938) were probably the first to succeed, for in the search for some experimental animal which would respond they found that large doses of $\beta$-naphthylamine given orally to dogs (300-450 mg. daily for twenty to thirty-two months) caused papillomatosis and carcinomatosis in twelve of sixteen animals. Bonser treated dogs with specially purified $\beta$-naphthylamine and confirmed Hueper's findings that species differences in the experimental animals are of importance; she was unable to induce bladder tumours in CBA mice using $\beta$-naphthylamine, although mice of this strain are very liable to bladder cancer when injected with the versatile carcinogen, 2-acetylaminofluorine. Wilson, De Eds, and Cox (1941) found in 1941 that it could evoke carcinoma of the bladder and other organs in a large proportion of albino rats of the Slonaker colony, but Wistar rats did not react in the same way; when the acetyl compound was tested on five different strains of mice all gave some bladder tumours, and in $18 \mathrm{CBA}$ strain mice fourteen tumours arose, 86 per cent. of which were malignant.

Not only are dye intermediates (that is, aromatic amines) carcinogenic for the bladder in animals, but also the finished products themselves when these are given orally. The Japanese workers have been prominent in this branch of the subject ; Yoshida in 1935 reported bladder papillomata in thirty-six of 168 rats fed with o-aminoazotoluene and Otsuka and Nagao also described bladder papillomas in thirteen of thirty rats fed with o-m'-dimethylazokenzene. In an attempt to see whether the effect of the carcinogen is via the urine, Berenblum and Bonser, using mice, examined the effect of the urine of workers from a dye factory, but with negative results.

Strömbeck made grafts of pieces of rat bladder epithelium into the livers of other rats which were fed with a diet of rice flour and azotoluene. A proportion of the intact bladders became papillomatous and hyperkeratotic, while the grafts remained free from metaplasia or papillomas, showing that

$$
\text { C }
$$

the origin of the tumours was urogenous rather than hæmatogenous.

\section{Carcinogenic Action of 2-Acetylaminofluorene}

This carcinogen (AAF) (fig. 36) has the peculiarity of inducing tumours in a number of organs and tissues when it is added to the diet of animals such as the mouse, rat, fowl, and cat. Bielschowsky, using rats, found that they tolerated $4 \mathrm{mg}$. per day, which produced numerous neoplasms nearly all of epithelial origin; leukæmia and mesodermal tumours were rare, for only one uterine sarcoma arose in five hundred rats. In the head were found squamous keratinizing carcinomata of the ductus acusticus externus, and carcinomata of the eyelid originated in glandular structures; in the neck adenocarcinoma of the thyroid, and in stimulated hyperplastic thyroids malignant tumours, could be produced. Basal-celled carcinoma arose in the skin and mammary cancer in the breast, more frequently in Wistar rats than in piebald rats, and in the thorax there were adenomata and metastasising cancer of the lung; in cats microscopic nodules in the lung developed where the normal tissue was replaced by squamous keratinising, epithelium. In the abdomen, the liver, bladder, small intestine, colon, pancreas, stomach, and uterus have all more or less frequently responded to treatment with AAF.

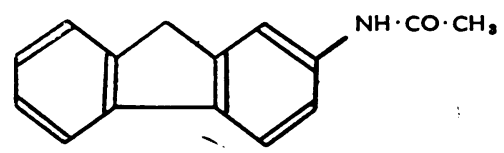

FIG. 36.-2-Acetylaminofluorene.

The genetic constitution and the age of the animal are important factors in the pathogenesis of these neoplasms. The combined administration of allylthiourea and AAF produced malignant tumours of the thyroid, and combined stilboestrol and AAF resulted in the growth of malignant tumours of the pituitary.

The tumours of the liver were very similar to those induced by another carcinogen, dimethylaminoazobenzene.

An analogous amine, 2-aminoanthracene which must be one of the very simplest carcinogens, was also found to be active, for it produced spindlecelled tumours of the skin in the rat.

\section{Production of Liver Tumours by Azo Compounds}

Orr's succinct article deals mainly with the carcinogenic action of p-dimethylaminoazobenzene 
(butter yellow, DMAB) (fig. 37), and also with o-aminoazotoluene (AAT) (fig. 38), which was the first azo compound found to be effective in liver tumour production by Yoshida in 1932 .

There is the usual tribute to organic chemical synthesis leading to the now familiar conclusion that no all-embracing co-relation can yet be made between chemical structure and carcinogenic potency, and there are also the facts about the susceptibility of species and strains of some experimental animals and the resistance of others.

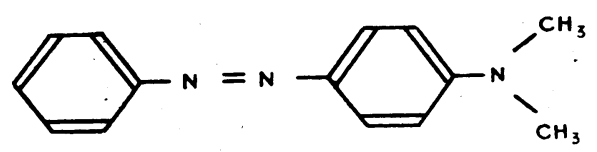

FIG. 37.-4-dimethylaminoazobenzene ("butter yellow").

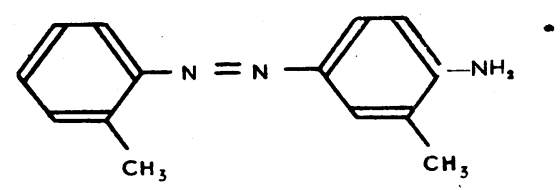

FIG. 38.-4'-animo-2 : 3'-azotoluene.

Some information about the administration and dosage of the two azo compounds would have been welcome.

Much work has been published on the effect of alterations in the diet although the results of such changes are difficult to explain.

Diets containing liver, kidney, rice, yeast, wheat flour, high levels of vitamin B, riboflavin, hydrogenated coconut oil, whole milk, and a high proportion of casein have all been reported as affording protection against liver carcinogenesis by azo compounds, but in some cases confirmation of the results by independent investigators could not be obtained.

Orr is scrupulously careful to quote both sides in controversies and such open mindedness will give satisfaction to the critical. For example, it is stated that (1) cirrhosis is frequently associated with subsequent hepatic carcinoma ; (2) tumours have been found in non-cirrhotic livers ; (3) cancer can develop at a stage when cirrhosis is reversible; (4) cirrhosis can be induced by DMAB in rabbits but liver cancer is unknown in this species.

Histologically liver tumours consist largely of two types, liver-cell carcinoma or hepatoma, and bile-duct carcinoma or cholangioma. It has been argued that if the action on the bile duct cells is direct, it would be possible to find extra-hepatic bile-duct carcinoma. In vitro experiments on cultures of liver cells and bile-duct epithelium treated with $\mathrm{N}: \mathrm{N}$-dimethyl-p-phenylenediamine show that the liver cells are much the more sensitive, and the same applies to the tumours derived from these tissues. The reason for the conclusion that this difference is strong evidence in favour of the existence of bile-duct carcinoma is not altogether clear.

Metabolic studies show that in the glycolytic activity of the tumours the substrate is glucose, whereas normal liver cells utilize glycogen and do not attack glucose. .

\begin{abstract}
"The fact that glucose-breakdown replaced glycogenolysis in the tumours was confirmed by Dickens and Weil-Malherbe (1943). They also investigated several highly-specialized functions of hepatic cells in the tumours, and found that the following were entirely, or almost entirely, lost : the formation of urea from ammonia or from $1(+)$-alanine, and of acetoacetic acid from caprylic acid ; the oxidation of uric acid ; and the synthesis of fermentable carbohydrate from pyruvic acid."

"Woodward (1943) showed that the alkaline - $\beta$-glycerophosphatase activity of DMAB tumours averaged ten times that of normal rat liver. Cohen (1945) found that, in rats receiving DMAB, the liver showed a progressively-decreasing glyoxalase activity; tumours and their transplants showed about ten per cent of the glyoxalase activity of norınal liver."
\end{abstract}

The mode of action of the azo carcinogens has been examined by a study of their-split products which were found to be toxic to various enzymes, for example, a diphosphopyridine nucleotide system, carboxylase, and a sulphydryl containing enxyme (urease). One of the metabolites, p-benzoquinone, is powerfully inhibitory to carboxylase. The view has been proposed that, although it is itself noncarcinogenic, the quinone is continuously renewed at sensitive sites in the tissues when the parent compound (DMA $\bar{B}$ ) is administered, and that detoxicating reactions never allow these sites to be reached by the quinone when it is itself given directly to the experimental animal.

\section{Occupational Cutaneous Cancer Attributable to Certain Chemicals in Industry}

Henry's fascinating account of pitch, tar, and oil cancer in workmen in industry is illustrated by selections from a classical collection of photographs of industrial processes which convey the atmosphere of authenticity by captions such as, "Females at slubbing frames in a cotton mill " or "Topman on a producer gas plant. Note position during prodding."

Historically, the study of industrial cancer was begun by Percival Pott in 1775, who had drawn 
attention to soot as a cause of scrotal cancer, and by Butlin in 1892, who showed that other substances-pitch, tar, and mineral oil-similarly affected the same site. Between 1907 and 1920 the list of diseases which were covered by the Factories Act (Workmen's Compensation) included " epitheliomatous ulceration and cancer due to pitch, tar, bitumen, paraffin, and mineral oil, or any compound or residue of any of these substances or any products thereof."

Between 1920 and 1945 the number of notifiable cases of cutaneous epithelioma amounted to 3,753 (occurring in nearly 3,000 persons) of which pitch, tar, or tar products. were held responsible for 2,229 (59.4 per cent.), and shale oil, mineral oil, or bitumen for $1,515(40 \cdot 3$ per cent.). Without data on the size of the population exposed to these substances, little idea can be obtained of the incidence rate: Henry gives a graph of the induction time before the disease is detected ; if frequency of incidence is plotted against time after commencement of employment, a steeple-shaped curve is obtained both for shale and mineral oils and for pitch, tar, and tar products, where the maximum number of cases in oil workers occurs after about fifty-two years and in pitch and tar workers after about twenty-two years. The shortest induction time for pitch and tar was ten months, and for oil four years.

Henry analyses in detailed tabular form the number of cases of cancer, occupation, site of the disease, and causal agent.

While the specialist in industrial cancer is chiefly interested in the statistical aspect of cancer incidence; he is also concerned with the application of the Compensation Act; and consequently Henry sometimes breaks off into a most interesting investigation of the occupational biography of a particular workman. For example :

"The man in question used only a Trinidad-Lake bitumen for the purpose, and in a previous communication I suggested that this case could be attributed to bitumen after twenty-one years' employment ; but further enquiry has now shown that he spent only just over two years in the special asphalt-trough department and that the previous nineteen years were occupied in cable-making, and so in contact with coal tar."

Again :

"There was, however, also an important case of epithelioma of the forehead in one man who had been a clerk for twenty-three years only in the office adjacent to the factory in which the pitch-dust was generated."

and

" Even a time-clerk for forty years and an ambulance room attendant were not exempt, but the latter had previously been a fitter on the plant ; while the history of removal of a keratotic growth from the head of a managing director is, no doubt, of interest."

It is a sad yet logical fact that the sufferings of the victims of industrial cancer should have initiated the onslaught on the problem of cancer by chemical technique.

\section{The Role of Arsenic in Carcinogenesis}

Currie, in discussing arsenic cancer, shows that the evidence comes largely from the disease in human subjects, in miners exposed to dust containing arsenides, in sheep-dip workers, and in patients with psoriasis who have been treated with arsenicals.

The radioactivity of the dust in the Schneeberg mines has suggested that the radiation and not arsenic is the cause of lung cancer occurring among cobalt miners, but the typical hyperkeratosis of arsenic intoxication on the palm of the hand has been observed in the men who wash the cobalt ores.

Just as the Schneeberg lung cancers have been attributed to radioactivity and not to arsenic, so pitch, tar, and mineral-oil cancer has been suggested as due to arsenic (Bayet and Slosse, 1919) who attempted to identify some common cause of industrial cancer.

It has been found, however, that the minute arsenic content of different tars bears no relation to their carcinogenic potency, that coal miners show no higher incidence than the general population, and that the keratosis of the palms and soles are not typical of pitch, tar, or mineral-oil cancer. Scott also concluded that arsenic was not the cause of the cancers seen in workers who use shale oil although the keratosis of the skin in these workers shows some resemblance to the chronic arsenical condition.

The commonest pathological changes in the skin of the hands and feet in arsenicism are hyperpigmentation (or -melanosis) and keratosis (which takes the form of corn-like elevations and occur in about 80 per cent. of the collected cases of arsenical skin cancer). In the great majority of 1.40 recorded cases the drug had been administered for a very long time, up to thirty years, but the high incidence in psoriatics treated medicinally has also been explained by a predisposition of the skin to cancer.

Kennaway's analysis of thirty-eight cases of arsenic cancer emphasizes that while in tar, pitch, and shale-oil cancer, the scrotum, head, and neck are the sites of election, in arsenic cancer 46 per cent. were located on fingers, legs, feet, toes, and trunk, 23 per cent. on arms and hands, 23 per cent. on scrotum, penis, head, face, neck, andi eyelid, and 8 per cent. on other parts.

Some sixty-five cases of skin cancer have been reported from Cordoba in Argentina, where water 
from some of the drinking wells was found on analysis to contain $0.45 \mathrm{mg}$. per cent. arsenic.

The re-production of arsenic cancer in experimental animals was accomplished by Leitch and Kennaway (1922), who found two tumours, one of them malignant, in two hundred mice which had been painted with potassium arsenite, and other investigators have induced sarcomatous changes in mice, chickens, and rabbits by parenteral injections.

\section{Occupational Cancer of the Bladder}

One of the longest articles in the Bulletin is Goldblatt's on cancer of the bladder in dye workers ; seven and a half pages, more than half, will interest chiefly medically qualified readers, for it consists of a survey of factory medical control, the signs and symptoms of the disease, pathogenesis and pathology, treatment and surgery, and surgical prognosis.

Of the numerous compounds used in the dye industry, only a few have been definitely assigned a urogenous carcinogenic role; these are $\beta$ naphthylamine and benzidine, and probably aniline and $\alpha$-naphthylamine ; hydrazobenzene is regarded as a potential carcinogen since it can easily give rise to aniline.

These compounds represent intermediate stages in the synthesis of dyes, and in some cases these stages are numerous; but examination indicates that the majority of bladder cancers occur in the workmen who are engaged on the process where the incriminated compound is actually produced or used, although absorption must occur wherever contaminated objects are handled, such as in laundries and repair shops.

The fumes, vapours, and dust of the dangerous substances are breathed, penetrate the clothes and skin, and in the past were taken in with the food. Efforts have been made in recent years to protect the dye workers by enclosing the plant, by conveying the intermediates in pipe-lines and other mechanical devices, and by general hygienic regulations ; but it is feared that some of the plant modifications and hygienic recommendations are as yet mere projects.

The bladder cancers now coming to hand were probably incurred at some time in the past, measured in decades, when it was considered more profitable to pay compensation than to redesign factory plant.

Experimental investigation with dye intermediates has been carried out on mice, rats, rabbits, monkeys, and dogs, in an attempt to reproduce bladder cancer in the laboratory; dogs responded to $\beta$-naphthylamine, but no animal tests have given positive results with benzidine, which is a potent carcinogen industrially. Such demonstrations of the difference in susceptibility of different species suggest that experimental evidence for the carcinogenic potency of dye intermediates is not an altogether satisfactory method of estimating toxicity for human subjects. Many of the compounds used in the dye industry, although not as yet known to be carcinogens, have a very harmful effect on the system, causing cyanosis, methæmaglobinæmia, and hæmorrhagic cystitis. These substances include " nitro compounds, amines, chloramines, nitroamines, phenols, diamines, chlor-nitro compounds, and derivatives of amides."

"It would appear almost as if the excitation of tumour formation by bladder irritants requires the latter to be $(a)$ of the less violent kind and $(b)$ exhibited in doses insufficient to lead to acute symptoms. In general terms, the tissue requires opportunity and time to react to the carcinogen, whereas the violent bladder-irritants break down the tissue reaction in its earliest stages. One of the most striking characters of these tumours is the furtive manner in which they develop, and another that they can arise long after all obvious exposure to the presumed carcinogen has ceased. The tumourforming process, nevertheless, is at some stage accompanied or preceded by evidence of instability of the lining membrane of the bladder (flaking-off of epithelial cells) and/or of inflammatory changes (leucocytes) in the urine."

Examination of the urine from the workmen or from experimental animals treated with the amines showed they are excreted as hydroxylated or acetylated derivatives or as compounds conjugated with sulphuric acid. Since phenols and acyl and aryl derivatives show no carcinogenic activity in workmen who are in contact with these substances, Goldblatt deduces that the amine itself, and not the hydroxyl, acetyl, or sulphuric acid derivative, is the effective carcinogen.

The latent period, that is, the interval between the first exposure to the carcinogenic compounds and the appearance of symptoms of the disease, was found by Goldblatt to be eleven to sixteen years in 54 per cent. of his cases, and twenty to forty-eight years in 19 per cent. Since the disease sometimes appears many years after occupational contact with the compounds has ceased, the period of exposure is different from the latent period. Here he found the shortest time was three and a half years and the longest thirty-three years, and in fifty-four cases 48 per cent. of the workmen had had three and a half to nineteen years in the industry and 13 per cent. had had twenty-six to thirty-three years.

In the dye workers, and also in experimental animals, the location of the tumour shows that they arise in those parts of the bladder which are exposed for the longest time to urine, and any decreased solubility of the amines and their metabolites owing 
to an increased alkalinity would lead to an accumulation of undissolved matter at the base of the bladder. Opinion is not yet unanimous on the question of whether the carcinogenic action is exerted by the dyes when they are in the urine or when they are still in the circulating blood. Goldblatt puts forward the speculation that two separate factors are concerned in bladder cancer, the endogenic factor and the "carcinogenic potentiator," that is, the amino compound.

The evidence advances in favour of this view are that carcinogens have been extracted from the urine of human subjects who were not dye workers (Steiner) and that location and histological characteristics show no fundamental differences between occupational and non-occupational bladder tumours. It is doubtful however, if such speculations without adequate factual support are very helpful. Goldblatt states :

"The presumption is that the carcinogen is present in greater or lesser degree in all, but that the tumour reaction will depend on the sufficiency of the carcinogen or on that of the potentiator. Such a hypothesis could perhaps account for the marked tendency to " recurrence "-i.e., once potentiated, always potentiated.

"Again, different individuals may be held to have varying amounts and availability of carcinogen and hence, even with the same amount of potentiation, varying response from none to extreme malignancy. (This is, of course, known among workers in aminobases.) The relative incidence of occupational bladder-tumours among young adults is much in excess of that of non-occupational tumours. This fact, on the above hypothesis, may be due to a marked potentiation of otherwise unsufficiently active carcinogen."

"The problem is clearly more subtle. The key lies, we suggest, in discovering first what structural or functional changes are brought about in the bladder epithelium by the presence of the amino-bases or their derivatives. One of the changes brought about, already referred to, is a disruption of the stability of the layers of epithelial cells.

The second necessary point to elucidate is the endogenous factor which, acting upon an epithelium which is attempting to regenerate, produces that extra stimulus which in the issue is carcinogenesis."

Goldblatt's article gives little idea of the incidence of bladder cancer in dye workers in relation to the number of workers at risk : there is not even some simple table of the number of annual cases. A variety of reasons contribute to this lacuna ; in the first place, the disease is not a notifiable industrial disease in Britain; secondly, the time of onset is very difficult to determine; thirdly, the absolute incidence of bladder cancer in the general population is considerable ; and, finally, it has been found impossible to estimate the number of workers in the dye industry who are actually exposed to the dangerous substances.

However, Hueper, in Occupational Tumours and Allied Diseases (1942), states that in small groups of workmen who receive continuous and massive doses of bladder carcinogens the frequency of the disease may be as high as 80 to 90 per cent., that investigators have found the cancer incidence to vary in different factories from 0.4 to 20 per cent., and that it has been reported that in Basel bladder cancer is thirty-three times as common in dye-workers as in the general male population.

\section{Chemotherapy of Cancer}

Haddow begins his discussion with a note on the history of cancer therapy by drugs in the last 1,500 years, when belladonna, aconite, mercury, antimony, and arsenic were all used, especially arsenic, which was still applied to chimney sweeps' cancer in the middle of the last century. The early therapists had every reason to be alive to the difficulties of the task, which has been made clearer today by the realization that the differences between normal and neoplastic tissue are almost too subtle to be revealed even by immunological characteristics; it is as though the mechanisms are different but the protein structures have been only slightly modified.

Haddow advances the revolutionary idea that a drug for cancer therapy which could selectively inhibit or kill cancer cells might undo the carcinogenic process and thus, by reversing the chain of events, drive back the cancer cells to differentiation and normality. Unfortunately, no evidence yet exists which might suggest that such reversal is possible.

At the present time, three types of chemical substances have been found to be of benefit in inhibiting tumours; these are: the cstrogens, used in cancer of the prostate ; the chlorethylamines, used in Hodgkin's disease and other lymphadenopathies ; and urethane, used in leukæmias. Treatment with œstrogens has so much in common with castration that Haddow devotes a passage to the results of the surgical method of treatment ; elsewhere, œstrogen therapy has been called " chemical castration."

Huggins, who is the authority in this field, found that in forty-five cases of advanced prostatic cancer treatment by bilateral orchidectomy caused sustained inhibition of the disease in thirty-one for thirty months; in nine improvement, and fiv

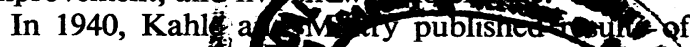
the treatment $w ; y$ strol of fourteen cal

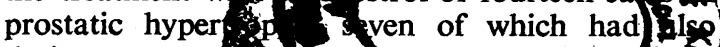
drainage opera s. In a these cases ther 
relief of symptoms of obstruction, and in 1942 Kahle and others reported on seven cases of carcinoma of the prostate which had been successfully treated with stilboestrol for two years. Kearns, in 1941, had found that thirty-seven patients with carcinoma of the prostate who had received œstrogens showed :

"... remarkable clinical amelioration, with gain in weight, relief of pain, improvement in blood-picture, slowing of sedimentation-rate, an approach to normal in the phosphatase estimations, retardation of growth in the skeletal metastases, with diminution in size and reduction of the nodularity and fixation of the prostate itself."

Haddow early in the development of the subject had treated a case of prostatic cancer with oestrogens and found improvement of the general condition ; and, although radiography did not give evidence of changes in the skeletal deposits, the patient is alive and well six years later. Haddow concludes that :

"No evidence exists that carcinoma of the prostate can be cured by the use of œstrogens, but there is equally little doubt that under this form of therapy the foci of the disease may become quiescent, that life can be prolonged, and that temporary rehabilitation can be achieved."

With regard to the mode of action of the cestrogens upon cancer of the prostate, there are a number of possibilities, for example, that there is a direct effect upon the prostatic epithelium via an inactivation of androgens, or by depression of the gonadotropic agents of the anterior pituitary, or by suppression of the activity of the interstitial cells of the testis. The malignant cells owe their sensitiveness to œstrogens to the retention of some physiological properties of the parent tissue. Haddow treated seventy-three cases of advanced cancer with synthetic œstrogens and found that in fifteen of thirty-six breast cases there was a significant but temporary retardation, and in thirty cases of cancer of other organs two responded by undoubted partial regression of the tumour.

" It is, of course, likely that such relatively massive doses of œstrogens depress the pituitary and hence the ovary, but it is specially important to decide whether the temporary nature of the tumour response is due to an endocrine adaptation to such depression, or to an acquired resistance on the part of the tumour cells themselves."

Mustard gas (bis ( $\beta$-chloroethyl) sulphide) and the nitrogen anglogue, i.e., $\beta$-chloroethylamine
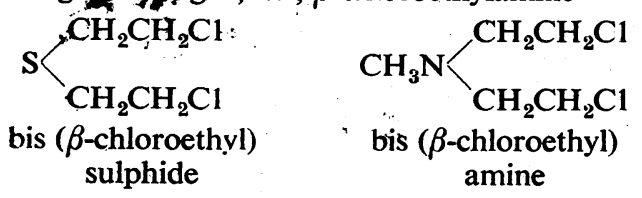

have not only a contact vesicant action on tissue but can also show profound cytotoxic effects, especially on tissues which are in active proliferation.

"For both sulphur and nitrogen-mustards, this relatively specific cytotoxic action upon growing tissues is an outstanding pharmacological property, and after adequate doses affects the bone-marrow in the production of leucopenia, thrombocytopenia and anæmia, the intestinal tract in the production of diarrhœa and vomiting, and lymphoid tissues generally in the appearance of persistent lymphatic atrophy. In attempts to ascertain the cytological basis of such effects, it has become clear that the mitotic activity of a variety of cells from unicellular, invertebrate, amphibian, mammalian and plant forms is highly sensitive to inhibition by mustard gas and the chloroethylamines."

Mustard gas greatly increases the spontaneous mutation rate of drosophila and of neurospora. The biological action of the nitrogen mustaids is believed to be due to the interaction of the cyclysed form with some tissue constituent :

“. . . the capacity of ethylenesulphonium or imonium compounds to alkylate such functional groups as various amino-, imino, imidazole, sulphydryl, sulphide and phenolic groups of amino acids and peptides; inorganic phosphate, glycerophosphate and hexose phosphates; the amino groups of adenosine and thiamine ; the pyridino- $\mathrm{N}$ of nicotinic acid amide and pyridoxine; and the carboxyl and amino groups of numerous proteins."

Mustard gas also attacks some enzyme systems. For example :

"In a long list of enzyme-systems of which the sensitivity has been determined, the majority proved either resistant or to be only moderately inhibited, but among the most highly sensitive systems are hexokinase, creatine and pyruvate phosphokinase, inorganic pyrophosphatase, adenylic acid deaminase, and cholinesterase."

However, mitotic changes can be produced by concentrations of the drug which are too low to affect respiration or glycolysis, and in experiments on transplantable tumours it has been found that the cells have been killed or at least made nontransplantable without showing morphological damage.

The nitrogen mustards were first tested clinically for chemotherapeutic effect in 1946, when encouraging results were seen in Hodgkin's disease; but in acute leukæmia, multiple myeloma, and myelogenous leukæmia the response was disappointing.

Lefèvre in 1939 had found that the mitotic effects induced by colchicine could be reproduced by phenylurethane, and Haddow and Sexton in 1946 showed that this compound was poisonous for the cells of the Lieberkuhn crypts in mouse intestine, 
that it retarded the growth of spontaneous mammary cancer and transplantable rat carcinoma, and, moreover, that urethane itself gave the same results.

The effect on the rat tumour was found to be " accompanied by a profound modification in the histological structure of the tumour, the characteristic cellular structure giving place to a more fibrous structure with an abundant stroma, and indicating a change in the direction of increased differentiation."

Urethane was tested on cases of breast carcinoma and other types of cancer, but the only promising results were obtained in leukæmia, where :

"Urethane does, in fact, produce remarkable changes in leukæmia, represented in the most favourable cases by a fall in total leucocyte-count to normal limits, a tendency for the differential count to approach a more normal pattern, diminution in the size of the spleen and enlarged lymph-nodes, and a rise in hæmoglobin level. There is a striking similarity between the leucocyte responses and those brought about by $x$-ray therapy. There is, however, no indication that permanent benefit may result from the use of urethane in either myeloid or lymphatic leukæmia, since relapses take place, immature cells may reappear in the blood, and all these changes are essentially reversible."

It was observed that various leukæmias in the rat and mouse were refractory to the action of urethane and thus the clinical test demonstrated species differences which could not have been predicted.

$$
\begin{gathered}
\mathrm{NH}_{2} \cdot \mathrm{CO} \cdot \mathrm{OC}_{2} \mathrm{H}_{5} \\
\text { urethane (ethyl carbamate) }
\end{gathered}
$$

The investigation of the mode of action of urethane has followed the conventional pattern, namely, tests on analogues of urethane, and the effect on tissues and tissue constituents such as enzymes.

Warburg (1910) had recorded that the narcotic action of phenylurethane inhibited cell division, and later he found that the dehydrogenases were similarly influenced ; but here again the concentrations required to induce narcosis or to suppress growth are much smaller than those required for enzyme inhibition. Keilin and Hartree (1939) concluded from a study of the components of the cytochrome enzyme system that urethane renders an essential part of the respiratory mechanism inaccessible to oxygen. Other investigators have suggested that urethane has an affinity for some special component of the cell or that it competes with a natural amine which is essential for the synthesis of nucleotides.

Urethane, colchicine, and also arsenic have in common the property of inhibiting mitosis, and they also have a retarding influence on leukæmia.
"It is an important problem whether the primary action of urethane is upon the growth-mechanism or upon differentiation-processes-to the extent that the two are separable. At the present moment one regards the latter as more likely, and can only suggest that the drug may act on growth primarily through the processes of maturation, and in leukæmia by tending to remedy some deficiency in these processes."

It is only too clear that the chemotherapeutic treatment for cancer is still in its infancy.

\section{REFERENCES}

Allen, E., and Gardner, W. V. (1941). Cancer Res., 1, 359. Bayet, A., and Slosse, A. (1919). Bull. Acad. Méd. Belg., 29, 607. Beck, S. (1941). Brit. J. exp. Path., 22, 299.

Kirby, A. H. M., and Peacock, P. R. (1945). Cancer Res., 5, 135.

, Prit. med. J., 1, 81.

Berenblum, I., and Bonser, G. M. (1937). J. industr. Hyg., 19, 86

Boyland, E., and Levi, A. A. (1935). Biochem. J., 29, 2678.

Boyland, E., and Levi, A. A. (1935).

二, - (1936 b). Ibid., 30, 1225.

Burrows, H., Hieger, I., and Kennaway, E. L. (1932). Amer. J. Cancer, 16, 57.

Butlin H. T. (1936). J. Path. Bact., 43, 419

Butlin, H. T. (1892). Brit. med. J., 1, 1341 ; 2, 1, 66.

Cohen, P. P. (1945). Cancer Res., 5, 626.

Cook, J. W. (1933). Proc. roy. Soc., B, 113, 277

Daudel, R. (1946 a). C. R. Acad. Sci., Paris, 222, 797.

(1946 b). Rev. Sci., Paris, 84, 37.

Dickens, F., and Weil-Malherbe, H. (1945). Biochem. J., 39, Proc.

Gardner, W. U., Dougherty, T. F., and Williams, W. L. (1944). Cancer Res., 4, 73.

-Kirschbaum, A., and Strong, L. C. (1940). Arch. Path., 29, 1.

Haddow, A., and Sexton, W. A. (1946). Nature, Lond., 157, 500.

Hieger, I. (1947). Brit. J. Radiol., 20, i45.

Hueper, W. C. (1942). "Occupational Tumours and Allied Diseases," Springfield, Illinois.

—, Wiley, F. H., and Wolfe, H. D. (1938). J. industr. Hyg., 20, 46.

Huggins, C: (1942). Ann. Surg., 115, 1192.

(1943 a). Science, 97,541 .

(1943 b). Penn. med.J., 46, 1023.

- (1943 c). N.Y. St. J. Med., 43, 519

- (1943 d). Conn. med.J., 7, 90.

- (1944 a). Canad. med. Ass. J., 50, 301

(1944 b). J. Amer. med. Ass., 124, 122.

(1946). Ibid. 131, 576.

Kahle, P. J., and Maltry, E. (1940). New Orleans med. Surg. J., 93, 121.

-,Ogden, H. D., and Getzoff, P. L. (1942 a), J. Urol., 48, 83.

, T. T1942 b). Urol. cutan. Rev., 46, 619 .

Kearns, W. M. (1941). Ann. Surg., 114, 886.

Keilin, D., and Hartree, E. F. (1939). Proc. roy. Soc. B., 127, 167

Kennaway, E. L. (1924). J. Path. Bact., 27, 233.

-(1925). Brit. med. J., $2,1$.

, and Hieger, I. (1930). Ibid., 1, 1044

Lefèvre, J. (1939). C. R. Acad. Sci., Paris, 208, 301

Leitch, A., and Kennaway, E. L. (1922). Brit. med. J., 2, 1107

Martin, M. (1946). C.R. Acad. Sci., Paris, 223, 508.

Pott, P. (1775). "Chirurgical Observations Relative to the Cataract, the Polypus of the Nose, the Cancer of the Scrotum, the different kind of Ruptures and the Mortification of the Toes and Feet." London.

Pullman, A. (1945). C.R. Acad. Sci., Paris, 221, 140.

1946 a). Ibid., 222, 392

(1946 b). Bull. Ass. franç. Cancer, 33, 120.

and Pullman, B. (1946). Experientia, 2, 364

Rous, P., and Kidd, J. G. (1941). J. exp. Med., 73, 365.

Schmidt, O. (1941). Naturwissenschaften, 29, 146.

Schmidt, O. (1941). Naturwissenschaften,

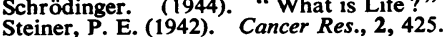

Steiner, P. E. (1942). Cancer

Strömbeck, J. P. (1946). J. Path. Bact., 58, 275.

Warburg, O. (1910). Hoppe-Seyl., Z., 66, 305 .

Weigert, F., and Mottram, J. C. (1946). Cancer Res., 6. 97, 109.

Wilson, R. H., De Eds, F., and Cox, A. J. (1941). Ibid., 1 ,

Wood, J. L., and Fieser, L. F. (1940). J. Amer. chem. Soc., 62, 2674. Woodward, H. Q. (1943). Cancer Res., 3, 159.

Wooley, G. W., Fekete. E., and Little, C. C. (1939). Proc. nat. Acad. Sci. Wsch., 25, 277.

Yamagiwa, K., end Ichikawa, K. (1915). Mitt. med. Fak. Tokio,

Yoshida, T. (1935). Gann, 29, 295. 